Research

\title{
A survey of irrigation water and soil quality that likely impacts paddy rice yields in Kilimanjaro, Tanzania
}

\author{
Fridolin M. Mpanda ${ }^{1} \cdot$ Mwemezi J. Rwiza ${ }^{1}$ - Kelvin M. Mtei ${ }^{1}$
}

Received: 22 July 2021 / Accepted: 9 November 2021

Published online: 29 November 2021

(c) The Author(s) 2021 OPEN

\begin{abstract}
In this study, the impacts of irrigation water quality and soil characteristics on paddy rice yields were investigated. Standard spectroscopy and spectrometry methods were used to analyze irrigation water and irrigated soil samples. The irrigation water had sodium adsorption ratio (SAR) values ranging from 0 to 3 . The corresponding electrical conductivity $(E C)$ values were between 0.2 and $0.7 \mathrm{dS} / \mathrm{m}$ and accounted for $14 \%$ of all samples-posing slight to moderate infiltration problem. Neither $\mathrm{Na}^{+}$nor $\mathrm{Cl}^{-}$levels were high enough to cause toxicity problems in the irrigation water. For $\mathrm{B}, 54 \%$ of the samples were found to have moderate toxicity whereas $\sim 14 \%$ of the samples indicated severe B toxicity in the irrigation water. For bicarbonate, about 86 and $14 \%$ of the irrigation water indicated slight-to-moderate and severe potential detrimental effect to plant growth, respectively. All trace elements in the irrigation water were too low to cause any harmful effect. Although soil EC, organic carbon (OC), and pH indicated favorable level, there were high standard deviation (SD) values in soil Fe and $\mathrm{Zn}$. The mean value of Fe in soils was $19.8 \mathrm{mg} / \mathrm{kg}$, indicating signs of Fe-deficiency. High SD values were also found in the total $\mathrm{N}(\mathrm{TN})$ content of the studied soils. Furthermore, a low soil K content was observed in the analyzed soil samples. Appropriate fertilizer application for improving nutrient deficiencies in the study area is highly recommended. Furthermore, on-farm management practices need to be guided by scientific findings from the present as well as other studies.
\end{abstract}

Keywords Irrigated soils characteristics · Irrigation water quality · Rice production · Smallholder rice farming · Kilimanjaro irrigation water $\cdot$ Tanzania

\section{Introduction}

Efforts have been made to improve irrigated farm yields in developing countries to meet the growing demands for rice. Despite such efforts, productivity is still lower than the genetic potential of $10 \mathrm{t} \mathrm{ha}^{-1}$. Paddy rice is grown in Africa using diverse production practices. These diverse production practices, ranging from primitive to highly mechanized methods, have led to variations in productivity [1].

In Tanzania, paddy rice is one of the most widely grown crops and is the second most important food crop [2]. The country has more than 21 million hectares suitable for paddy rice production. Paddy rice is grown under three

Supplementary Information The online version contains supplementary material available at https://doi.org/10.1007/s43832-02100008-0.

Mwemezi J. Rwiza, mwemezi.rwiza@nm-aist.ac.tz; Fridolin M. Mpanda, mpandaf@nm-aist.ac.tz; Kelvin M. Mtei, kelvin.mtei@nmaist.ac.tz | ${ }^{1}$ School of Materials, Energy, Water and Environmental Sciences (MEWES), The Nelson Mandela African Institution of Science and Technology (NM-AIST), P. O. Box, 447, Arusha, Tanzania.

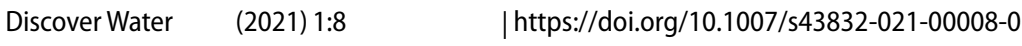


major ecosystems namely, rain-fed, upland, and irrigated. The rain-fed ecological system covers $74 \%$ of the current rice hectares with yields ranging from 1.0 to $2.0 \mathrm{t} \mathrm{ha}^{-1}$ while the irrigated ecosystem is about $20 \%$ with yields ranging from 2.5 to $4.0 \mathrm{t} \mathrm{ha}^{-1}$; the remaining $6 \%$ is under upland ecology [3]. Thus, variations in paddy yields in Tanzania and sub-Saharan Africa may be due to ecology, rainfall patterns, water quality and quantity, soil characteristics, rice varieties, diseases and pests, and other factors.

The irrigated ecosystem provides readily available water for paddy production. This accessibility to irrigation water coupled with high solar radiation and low incidence of pest and diseases may result into high paddy rice yields. However, the quality of irrigation water has been reported to influence paddy yields. The effects are usually related to the irrigation water physico-chemical properties. Issues related to irrigation water quality include high salinity levels which affect nutrients availability, high $\mathrm{Na}^{+}$levels which cause soil infiltration problems for irrigation water and toxicity of some elements when their levels in irrigation water are in excess. Dissolved salts and trace elements in irrigation water are usually due to natural weathering of the earth's crust or as a result of anthropogenic activities such as disposal of improperly treated wastewater and sludge as well as excessive use of fertilizers. Therefore, improved management practices of irrigation water quality may be necessary for higher paddy rice yields.

Soil properties have also been reported as a contributing factor to rice growth. Usually, nutrient content and availability in soils determine the chemical properties of that soil. Soils with high organic matter (OM) content are known to hold more nutrients necessary for paddy growth. Also, as soil OM content increases from 0.5 to $3.0 \%$, the available water-holding capacity in the soil also increases [4]. Therefore, low OM or losses of OM in the soils can significantly reduce paddy rice yields.

Tanzania, like other developing countries in sub-Saharan Africa, is struggling to improve its rice yields. For instance, in the present study area, rice yields have been ranging from 0.4 to $3.8 \mathrm{t} \mathrm{ha}^{-1}$ (average $1.87 \mathrm{t} \mathrm{ha}^{-1}$; Table S3-Supplementary Material). These yields were low compared to those in countries such as Egypt and USA where the average rice yields are close to $10 \mathrm{t} \mathrm{ha}^{-1}$ [5]. Smallholder paddy rice growers at the present study sites have been complaining about uneven and low production leading to low family income. Therefore, this study aimed at assessing the impacts of irrigation water quality and soil characteristics on paddy rice productivity in the area that has been poorly investigated.

\section{Materials and methods}

\subsection{Area and general methods}

The study was carried out at one of the irrigated areas/sectors in the Kilimanjaro region of Northern Tanzania (Fig. 1). The study area is located in Mwanga District. It shares borders with Simanjiro District to the West, Moshi District to the North, the Republic of Kenya to the East and Same district to the South. The studied sectors abstract their water from the Ivonokwa and Mtindi springs, which supply water to Kivulini, Bogoyo, and Nanyori.

The sampling sites were randomly selected, and their respective geographical positioning were determined using a handheld geographical positioning system (GPS) device (Garmin International, Inc., East Street 151 East Street, Olathe, Kansas). A QGIS software Version 2.1.8 was used to prepare the map showing sampling points in the study area. The study area was further divided into three sectors i.e., Kivulini, Nanyori, and Bogoyo using the three main canals as points of reference (Fig. 2). The sectors were used for comparison purposes. The one-way analysis of variance (ANOVA) for the three sectors was computed using the SigmaPlot software; the degree of freedom, $F$ - and $P$-values are presented in Tables S1 and S2 in the Supplementary Material.

A reconnaissance survey was conducted prior to irrigation water and soil sample collection (Supplementary Material, Table S3). It was found that the amount of the irrigation water that was supplied to the individual farms through the irrigation canals was enough to meet paddy rice water requirements. Therefore, water supply to the rice farms was not a problem. The farmers that were interviewed revealed that they used fertilizers during the S0-S1 stage, following the Counce et al. [6] rice development staging system) to facilitate seed germination. They also revealed that they applied fertilizers to boost rice growth around Counce et al.'s V3-V7 stages. Boosting fertilization was done 14 days after transplanting. The final fertilization round was conducted during the R6-R7 stages [6] as paddy rice approached maturity. 
Fig. 1 Map of the study area. Map A represents Tanzania country with all the regions. Map B represents Kilimanjaro region and Map C represents the study region. The details of map C are shown in Fig. 2
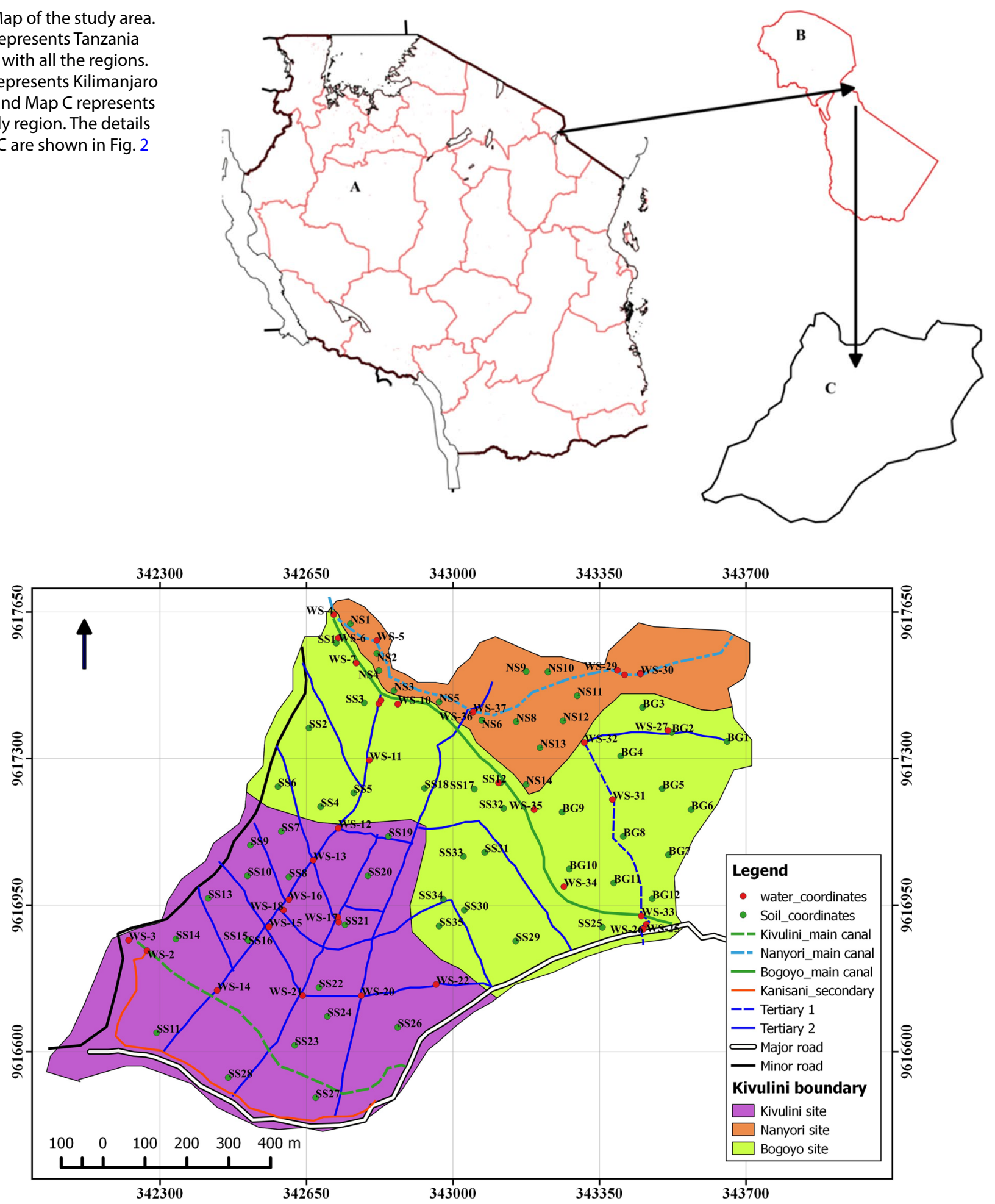

Fig. 2 Layout map of the sampling area. The map shows three areas of Kivulini (purple), Bogoyo (green) and Nanyori (orange) where irrigation water and soil samples for this study were collected

\subsection{Irrigation water sampling}

Irrigation water and soil sample collection was performed in July 2018. The farmers in the study area have two growing seasons. A season from February to May (long rain season) and the one from August to December that experiences short 
rains. The irrigation water is mostly needed in the August to December season. That was the target of the present study. The limitation of this study is that sampling in different months may yield different results as this study is a representation of a dry season. A total of 37 irrigation water samples were collected and stored in $1.0 \mathrm{~L}$ glass bottles with Teflon-lined lids. Before sample collection, the bottles were triple rinsed with deionized water. All other sampling procedures are described below.

Seventeen (17) irrigation water samples were collected from irrigation ditches located on 17 individual farms whereas the other 20 irrigation water samples were collected from the main drainage and distribution canals. During water sample collection, some physico-chemical properties of water were recorded onsite using a multi-parameter device (Model HI 9828, HANNA Instruments, Italy). Data recorded onsite included the irrigation water $\mathrm{pH}, \mathrm{EC}$, TDS, temperature, salinity, dissolved oxygen (DO) and the oxidation reduction potential (ORP). The bottles were then sealed, labeled, preserved in a cool box, and transported to the Nelson Mandela African Institution of Science and Technology (NM-AIST) laboratory for further analyses. At NM-AIST, the samples were acidified using analytical grade $\mathrm{HNO}_{3}$ to a pH less than 2 . The irrigation water samples were then refrigerated at $4{ }^{\circ} \mathrm{C}$ to minimize microbial activity and undesirable physicochemical reactions before further analysis.

\subsection{Sampling of irrigated soils}

Soil samples were collected across the three regions shown in Fig. 2 at the same time as when the water samples were collected. A total of 61 soil samples were collected at a depth of 0 to $20 \mathrm{~cm}$ at different locations in the study area. The 'up to $20 \mathrm{~cm}$ ' is the depth of tillage that is common for irrigated rice growing in Tanzania. The presence of a hardpan limits the depth to which farmers can go when tilling the rice fields and the avoidance of the disruption of the soil's water retention capacity thereof. To obtain one representative sample on a site, six points were randomly selected across a field/farm; the six soil samples were composited and thoroughly mixed before a final composite sample of $0.5 \mathrm{~kg}$ was removed for analysis. The composite samples were stored in labeled zip-top bags and transported to the NM-AIST laboratory for analysis. Accordingly, all other soil sampling procedures were followed using the recommendations in the literature [7].

\subsection{Laboratory methods}

Irrigation water samples were analyzed for cations $\left(\mathrm{Ca}^{2+}, \mathrm{Mg}^{2+}, \mathrm{K}^{+}, \mathrm{Na}{ }^{+}\right)$, anions $\left(\mathrm{SO}_{4}^{2-}, \mathrm{PO}_{4}^{2-}, \mathrm{CO}_{3}^{2-}, \mathrm{HCO}_{3}^{-}, \mathrm{Cl}^{-}, \mathrm{NO}_{3}^{-}\right)$and heavy metals $\left(\mathrm{Fe}^{2+}, \mathrm{Zn}^{2+}, \mathrm{Cu}^{2+}, \mathrm{Mn}^{2+}, \mathrm{B}, \mathrm{As}, \mathrm{Cd}_{1} \mathrm{Cr}^{2+}, \mathrm{Pb}^{2+}, \mathrm{Ni}^{2+}\right.$ and $\left.\mathrm{Al}^{3+}\right)$ using the methods explained in Table 1.

Moreover, SAR (in meq/L) for irrigation water samples was calculated using a standard Eq. (1) [8]:

$$
\mathrm{SAR}=\frac{\left[\mathrm{Na}^{+}\right]}{\sqrt{\frac{\left[\mathrm{Ca}^{2+}\right]+\left[\mathrm{Mg}^{2+}\right]}{2}}}
$$

where $\left[\mathrm{Na}^{+}\right],\left[\mathrm{Ca}^{2+}\right]$, and $\left[\mathrm{Mg}^{2+}\right]$ are concentrations of sodium, calcium and magnesium ions in the irrigation water samples, respectively.

Soil samples were analyzed for $\mathrm{OC}, \mathrm{EC}, \mathrm{pH}, \mathrm{Fe}^{2+}, \mathrm{Zn}^{2+}, \mathrm{N}, \mathrm{P}$ and $\mathrm{K}^{+}$using standard methods for soil analysis. A summary of methods used for measurement of irrigated soil quality is presented (Table 2).

\section{Results}

\subsection{Irrigation water and salinity problems}

When the EC values were converted to $\mathrm{dS} / \mathrm{m}$, the results indicated that $14 \%$ of the assessed irrigation water samples had EC values $<0.7 \mathrm{dS} / \mathrm{m}$ (Table 3 ). The remaining $86 \%$ of the assessed irrigation water samples indicated slight to moderate restriction level. No sample had EC values in the severe category of restriction for irrigation use.

\subsection{Analysis of SAR levels}

All the irrigation water samples' SAR values fell between 0 and 3 (Table 4). When interpreted alongside the corresponding EC values, the results indicated that only $14 \%$ of the irrigation water samples had EC values between 0.2 


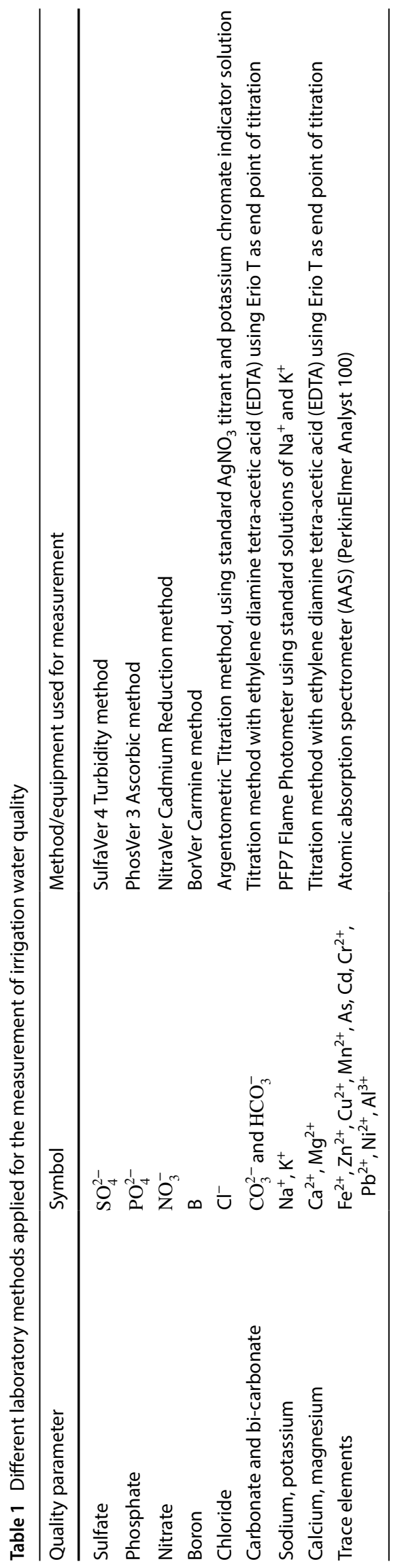


Table 2 Different methods used for measurement of irrigated soil quality parameters

\begin{tabular}{|c|c|c|}
\hline Quality parameter & Symbol & Method/equipment used in measurement \\
\hline Electrical conductivity, $\mathrm{pH}$ & $\mathrm{EC}, \mathrm{pH}$ & $\begin{array}{l}\text { A portable meter using a soil to water ratio of } 1: 2 \text { with potas- } \\
\text { sium chloride reagent }\end{array}$ \\
\hline Organic carbon & OC & Mixing the sample with chromic acid and $\mathrm{H}_{2} \mathrm{SO}_{2}$ \\
\hline Total nitrogen & Total N (TN) & The Micro-Kjeldahl digestion, distillation followed by titration \\
\hline Available phosphorus & Available P & Olsen method \\
\hline Potassium & $\mathrm{K}^{+}$ & Flame Photometer method \\
\hline Iron, zinc & $\mathrm{Fe}^{2+}, \mathrm{Zn}^{2+}$ & $\begin{array}{l}\text { Atomic absorption spectrophotometer (AAS) after digestion } \\
\text { and extraction of samples }\end{array}$ \\
\hline
\end{tabular}

and $0.7 \mathrm{dS} / \mathrm{m}$. The remaining $86 \%$ of the irrigation water samples had EC values $>0.7 \mathrm{dS} / \mathrm{m}$. None of the 37 samples had EC values below $0.2 \mathrm{dS} / \mathrm{m}$.

\subsection{Water pH and EC levels}

Irrigation water $\mathrm{pH}$ levels for the Kivulini sites ranged from 6.25 to 7.42 with a mean value of $6.64 \pm 0.45$ (Table 5) while that of the Nanyori samples ranged from 6.27 to 7.23 and averaged $6.6 \pm 0.35$ (Table 6). For the Bogoyo area, the pH values ranged from 6.23 to 7.35 with an average value of $6.71 \pm 0.37$ (Table 7). The ANOVA values showed that there were no statistically significant differences in $\mathrm{pH}$ levels among the three areas surveyed $(F=1.09, P=0.35)$ (Table $\mathrm{S} 1$ ). The EC values for the Kivulini area varied from 662 to $1365 \mu \mathrm{S} \mathrm{cm}{ }^{-1}$ with a mean value of $942.62 \pm 188.85 \mu \mathrm{S} \mathrm{cm}{ }^{-1}$ (Table 5) and that of the Nanyori area varied from 669 to $1027 \mu \mathrm{S} \mathrm{cm}^{-1}$ with an average value of $856.86 \pm 139.96 \mu \mathrm{S}$ $\mathrm{cm}^{-1}$ (Table 6). The Bogoyo area (Table 7) had its EC values ranging from 656 to $1515 \mu \mathrm{Sm}^{-1}$ with a mean value of $1013.53 \pm 265.58 \mu \mathrm{S} \mathrm{cm}^{-1}$. The ANOVA showed no statistical significant difference in EC levels among the three subregions in EC levels $(F=0.42, P=0.66)$ (Table $S 1)$.

\subsection{Irrigation water essential elements}

For the Kivulini area (Table 5), the concentrations of $\mathrm{Ca}^{2+}$ ranged from 32.06 to $76.15 \mathrm{mg} \mathrm{L}^{-1}$ and averaged $52.11 \pm 13.98 \mathrm{mg} \mathrm{L}^{-1}$ while for the Nanyori region (Table 6) the $\mathrm{Ca}^{2+}$ concentrations ranged from 40.08 to $64.13 \mathrm{mg}$ $\mathrm{L}^{-1}$ with an average value of $55.54 \pm 10.96 \mathrm{mg} \mathrm{L}^{-1}$. The $\mathrm{Ca}^{2+}$ levels for the Bogoyo study area ranged from 32.06 to $76.15 \mathrm{mg} \mathrm{L}^{-1}$ with a mean value of $52.58 \pm 10.97 \mathrm{mg} \mathrm{L}^{-1}$ (Table 7). The one-way ANOVA showed that there were no significant differences in $\mathrm{Ca}^{2+}$ levels among the areas surveyed $(F=0.36, P=0.7)$ (Table S1). The $\mathrm{Mg}^{2+}$ levels for the Kivulini area ranged from 21.87 to $75.33 \mathrm{mg} \mathrm{L}^{-1}$ and averaged $37.35 \pm 16.35 \mathrm{mg} \mathrm{L}^{-1}$ (Table 5) while that of the Nanyori area ranged from 23.09 to $39.37 \mathrm{mg} \mathrm{L}^{-1}$ with a mean value of $31.24 \pm 5.18 \mathrm{mg} \mathrm{L}^{-1}$ (Table 6). The Bogoyo area had $\mathrm{Mg}^{2+}$ levels ranging from 23.09 to $52.97 \mathrm{mg} \mathrm{L}^{-1}$ with an average value of $34.96 \pm 9.15 \mathrm{mg} \mathrm{L}^{-1}$ (Table 7). Similar to the preceding cations mentioned above, the ANOVA showed no statistically significant difference in $\mathrm{Mg}^{2+}$ levels among the three areas surveyed $(F=2.81, P=0.08)$ (Table $S 1)$.

The $\mathrm{K}^{+}$levels for the Kivulini area ranged from 2.03 to $12.46 \mathrm{mg} \mathrm{L}^{-1}$ with a mean value of $4.75 \pm 2.83 \mathrm{mg} \mathrm{L}^{-1}$ (Table 5); for the Nanyori area the values ranged from 3.41 to $28.90 \mathrm{mg} \mathrm{K}^{+} \mathrm{L}^{-1}$ (Table 6) with a mean value of $14.47 \pm 7.38 \mathrm{mg} \mathrm{L}^{-1}$. For the Bogoyo sector (Table 7), the $\mathrm{K}^{+}$levels ranged from 4.36 to $56.20 \mathrm{mg} \mathrm{L}^{-1}$ with a mean value of $18.06 \pm 13.11 \mathrm{mg}$ $\mathrm{L}^{-1}$. The ANOVA values revealed that there were no significant differences in $\mathrm{K}^{+}$levels among the three areas $(F=0.47$, $P=0.63$ ) (Table S1). The $\mathrm{Na}^{+}$levels in the Kivulini sites (Table 5) ranged from 3.61 to $39.98 \mathrm{mg} \mathrm{L}^{-1}$ with a mean value of $19.66 \pm 10.32 \mathrm{mg} \mathrm{L}^{-1}$ while that of the Nanyori area (Table 6) ranged from 8.85 to $23.38 \mathrm{mg} \mathrm{L}^{-1}$ with an average value of $14.95 \pm 4.55 \mathrm{mg} \mathrm{L}^{-1}$. The Bogoyo area (Table 7) had Na+ levels ranging from 3.41 to $56.2 \mathrm{mg} \mathrm{L}^{-1}$ with a mean value of $16.5 \pm 12.7 \mathrm{mg} \mathrm{L}^{-1}$. The ANOVA output showed no statistically significant differences in $\mathrm{Na}^{+}$levels among the three areas surveyed $(F=036, P=0.70)$ (Table 5).

The phosphorus (P) levels in the Kivulini area ranged from 0.14 to $0.82 \mathrm{mg} \mathrm{L}^{-1}$ with a mean value of $0.24 \pm 0.18 \mathrm{mg} \mathrm{L}^{-1}$ (Table 5) and that of the Nanyori area ranged from 0.19 to $0.25 \mathrm{mg} \mathrm{L}^{-1}$ with an average of $0.22 \pm 0.02 \mathrm{mg} \mathrm{L}^{-1}$ (Table 6). The Bogoyo area had P levels ranging from 0.11 to $0.95 \mathrm{mg} \mathrm{L}^{-1}$ with a mean value of $0.38 \pm 0.25 \mathrm{mg} \mathrm{L}^{-1}$ (Table 7). Furthermore, 
Table 3 FAO guidelines for interpretation of water quality for irrigation [9] vs. field data from the studied area considering salinity effect

\begin{tabular}{|c|c|c|c|c|c|c|}
\hline \multirow{3}{*}{$\begin{array}{l}\text { Parameter (unit) } \\
\text { Degree of restriction }\end{array}$} & \multicolumn{6}{|c|}{ Salinity measure } \\
\hline & \multicolumn{3}{|c|}{$\mathrm{EC}(\mathrm{dS} / \mathrm{m})$} & \multicolumn{3}{|c|}{ TDS (mg/L) } \\
\hline & None & Slight to moderate & Severe & None & Slight to moderate & Severe \\
\hline FAO guideline & $<0.7$ & $0.7-3.0$ & $>3.0$ & $<450$ & $450-2000$ & $>2000$ \\
\hline \multicolumn{7}{|c|}{ Levels in field samples for the current study } \\
\hline \multicolumn{7}{|l|}{ Site name } \\
\hline WS-1 & 0.66 & & & 429 & & \\
\hline WS-2 & 0.93 & & & 601 & & \\
\hline WS-3 & 0.82 & & & 535 & & \\
\hline WS-4 & 0.67 & & & 436 & & \\
\hline WS-5 & 0.71 & & & 461 & & \\
\hline WS-6 & 0.96 & & & 624 & & \\
\hline WS-7 & 1.13 & & & 735 & & \\
\hline WS-8 & 0.93 & & & 603 & & \\
\hline WS-9 & 0.92 & & & 599 & & \\
\hline WS-10 & 0.99 & & & 646 & & \\
\hline WS-11 & 1.46 & & & 1462 & & \\
\hline WS-12 & 1.37 & & & 1365 & & \\
\hline WS-13 & 0.82 & & & 533 & & \\
\hline WS-14 & 0.84 & & & 543 & & \\
\hline WS-15 & 0.95 & & & 619 & & \\
\hline WS-16 & 1.05 & & & 683 & & \\
\hline WS-17 & 1.19 & & & 779 & & \\
\hline WS-18 & 1.09 & & & 703 & & \\
\hline WS-19 & 0.95 & & & 618 & & \\
\hline WS-20 & 0.89 & & & 579 & & \\
\hline WS-21 & 0.82 & & & 534 & & \\
\hline WS-22 & 0.82 & & & 533 & & \\
\hline WS-23 & 0.98 & & & 636 & & \\
\hline WS-24 & 0.98 & & & 637 & & \\
\hline WS-25 & 0.98 & & & 632 & & \\
\hline WS-26 & 1.16 & & & 754 & & \\
\hline WS-27 & 1.52 & & & 983 & & \\
\hline WS-28 & 1.03 & & & 667 & & \\
\hline WS-29 & 0.86 & & & 560 & & \\
\hline WS-30 & 0.99 & & & 642 & & \\
\hline WS-31 & 1.17 & & & 759 & & \\
\hline WS-32 & 1.37 & & & 890 & & \\
\hline WS-33 & 0.66 & & & 424 & & \\
\hline WS-34 & 0.71 & & & 458 & & \\
\hline WS-35 & 0.66 & & & 427 & & \\
\hline WS-36 & 0.67 & & & 434 & & \\
\hline WS-37 & 0.79 & & & 510 & & \\
\hline
\end{tabular}

the ANOVA values indicated that the Kivulini area differed significantly from the Nanyori and Bogoyo areas in P levels $(F=4.10, P=0.03)$ (Table S1). 
Table 4 FAO guidelines for interpretation of water quality for irrigation [9] vs. field data from the studied area considering infiltration and sodium toxicity effect

\begin{tabular}{|c|c|c|c|c|c|}
\hline \multirow{3}{*}{$\begin{array}{l}\text { Parameter (unit) } \\
\text { Degree of restriction }\end{array}$} & \multicolumn{5}{|c|}{ Infiltration measure } \\
\hline & \multicolumn{2}{|l|}{ SAR (meq/L) } & \multicolumn{3}{|c|}{$\mathrm{EC}(\mathrm{dS} / \mathrm{m})$} \\
\hline & & & None & Slight to moderate & Severe \\
\hline \multirow[t]{5}{*}{ FAO guideline } & SAR 0-3 & with $\mathrm{EC}=$ & $>0.7$ & $0.7-0.2$ & $<0.2$ \\
\hline & SAR 3-6 & with $\mathrm{EC}=$ & $>1.2$ & $1.2-0.3$ & $<0.3$ \\
\hline & SAR 6-12 & with $\mathrm{EC}=$ & $>1.9$ & $1.9-0.5$ & $<0.5$ \\
\hline & SAR 12-20 & with $\mathrm{EC}=$ & $>2.9$ & $2.9-1.3$ & $<1.3$ \\
\hline & SAR 20-40 & with $\mathrm{EC}=$ & $>5.0$ & $5.0-2.9$ & $<2.9$ \\
\hline \multicolumn{6}{|c|}{ Levels in field samples for the current study } \\
\hline \multicolumn{6}{|c|}{ Site name } \\
\hline WS-1 & 0.32 & & 0.66 & & \\
\hline WS-2 & 0.57 & & 0.93 & & \\
\hline WS-3 & 0.97 & & 0.82 & & \\
\hline WS-4 & 0.21 & & 0.67 & & \\
\hline WS-5 & 0.41 & & 0.71 & & \\
\hline WS-6 & 0.48 & & 0.96 & & \\
\hline WS-7 & 1.72 & & 1.13 & & \\
\hline WS-8 & 0.31 & & 0.93 & & \\
\hline WS-9 & 0.37 & & 0.92 & & \\
\hline WS-10 & 0.64 & & 0.99 & & \\
\hline WS-11 & 0.51 & & 1.46 & & \\
\hline WS-12 & 0.53 & & 1.37 & & \\
\hline WS-13 & 0.64 & & 0.82 & & \\
\hline WS-14 & 0.56 & & 0.84 & & \\
\hline WS-15 & 0.33 & & 0.95 & & \\
\hline WS-16 & 0.24 & & 1.05 & & \\
\hline WS-17 & 0.84 & & 1.19 & & \\
\hline WS-18 & 0.71 & & 1.09 & & \\
\hline WS-19 & 0.35 & & 0.95 & & \\
\hline WS-20 & 0.50 & & 0.89 & & \\
\hline WS-21 & 0.22 & & 0.82 & & \\
\hline WS-22 & 0.10 & & 0.82 & & \\
\hline WS-23 & 0.11 & & 0.98 & & \\
\hline WS-24 & 0.09 & & 0.98 & & \\
\hline WS-25 & 0.75 & & 0.98 & & \\
\hline WS-26 & 0.13 & & 1.16 & & \\
\hline WS-27 & 0.61 & & 1.52 & & \\
\hline WS-28 & 0.58 & & 1.03 & & \\
\hline WS-29 & 0.45 & & 0.86 & & \\
\hline WS-30 & 0.47 & & 0.99 & & \\
\hline WS-31 & 0.31 & & 1.17 & & \\
\hline WS-32 & 0.20 & & 1.37 & & \\
\hline WS-33 & 0.41 & & 0.66 & & \\
\hline WS-34 & 0.33 & & 0.71 & & \\
\hline WS-35 & 0.29 & & 0.66 & & \\
\hline WS-36 & 0.26 & & 0.67 & & \\
\hline WS-37 & 0.29 & & 0.79 & & \\
\hline
\end{tabular}




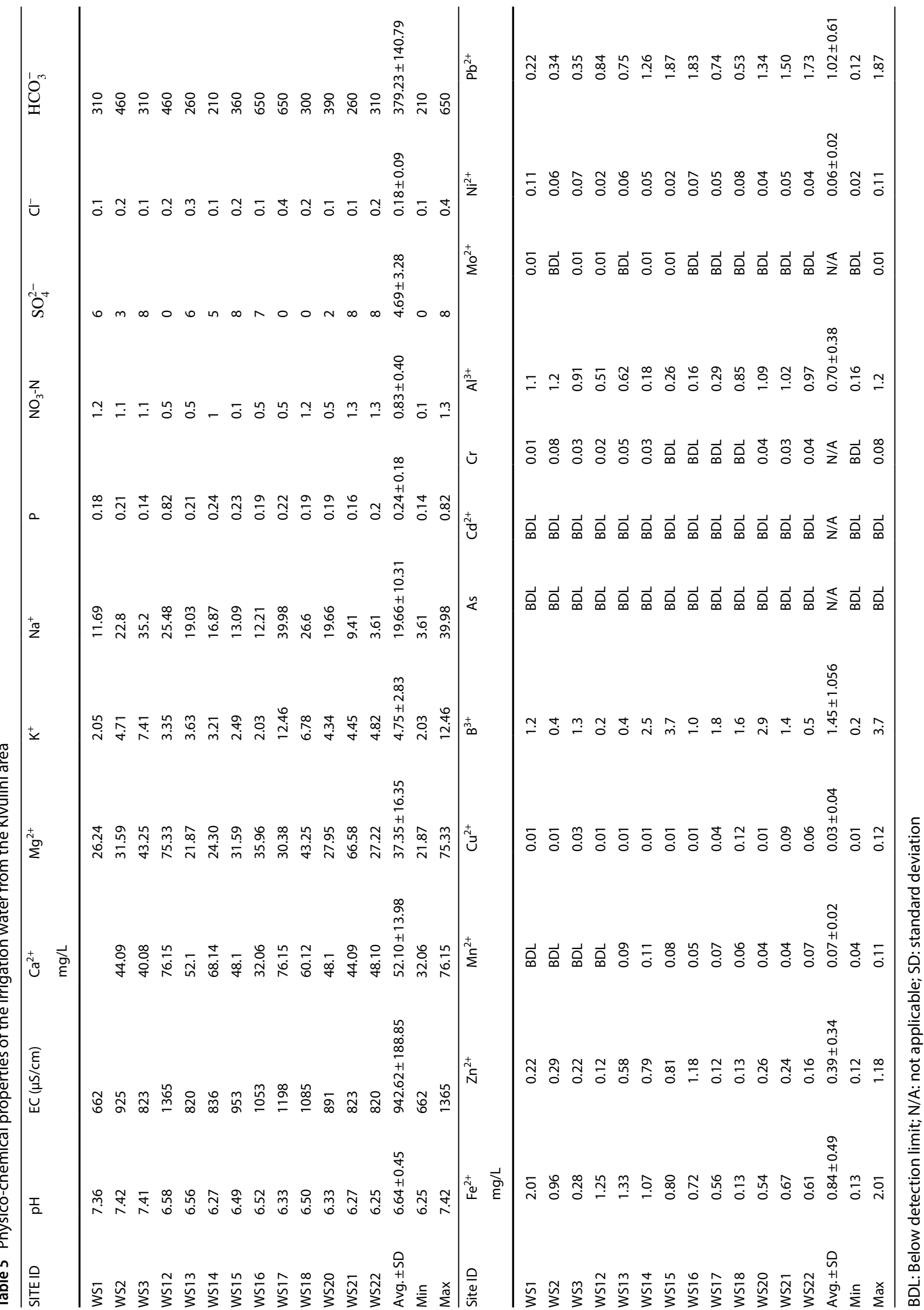




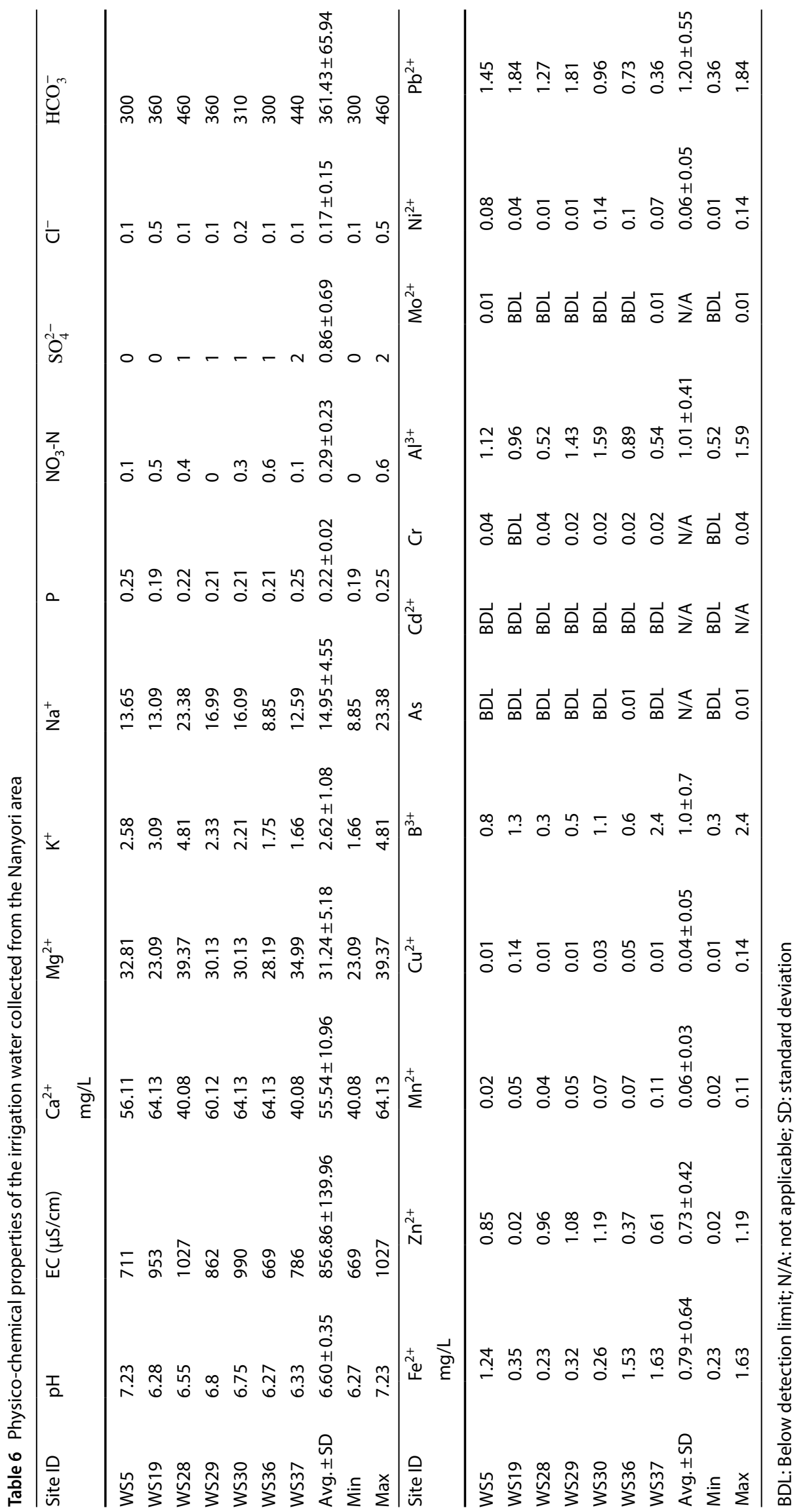




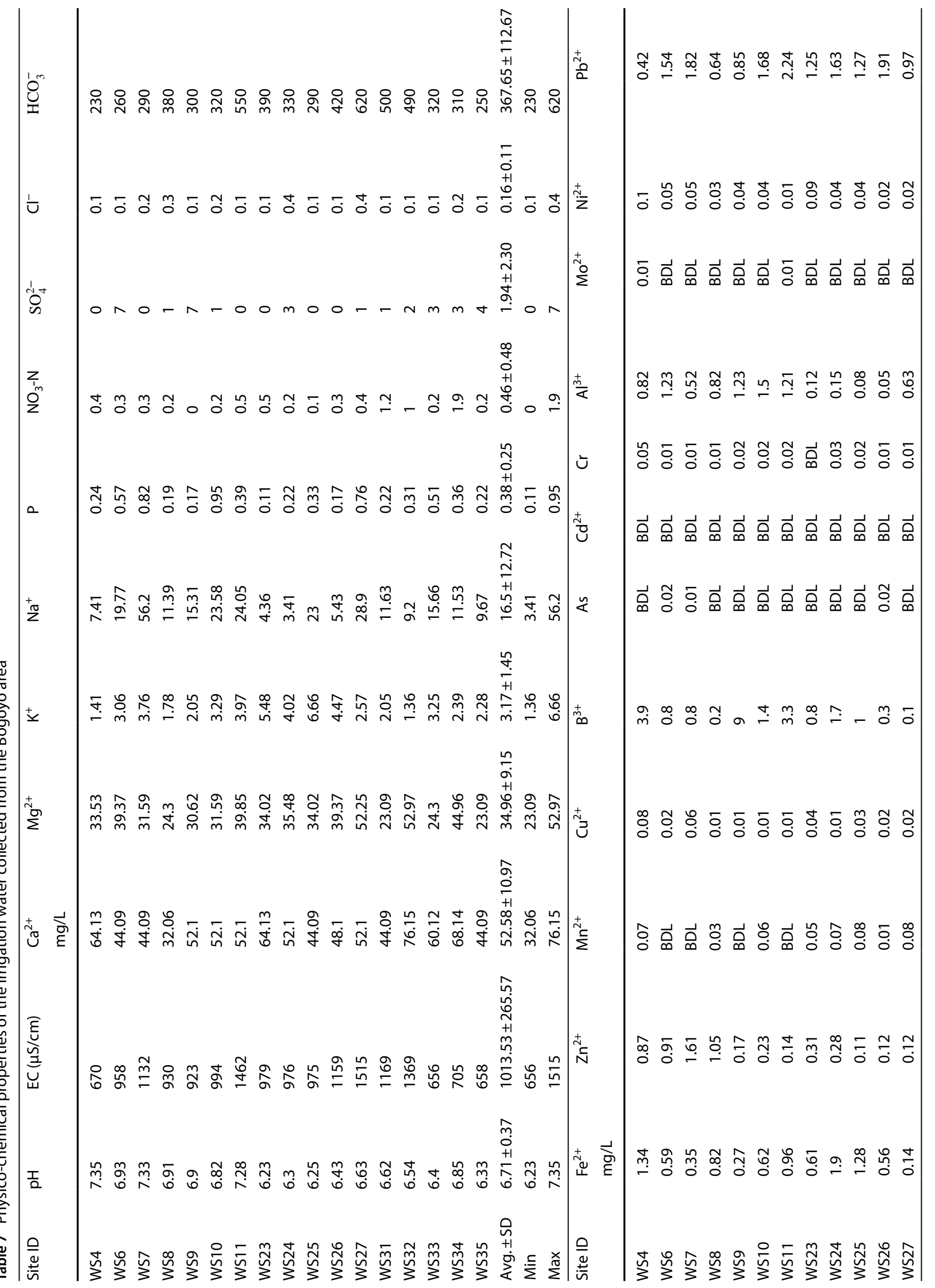




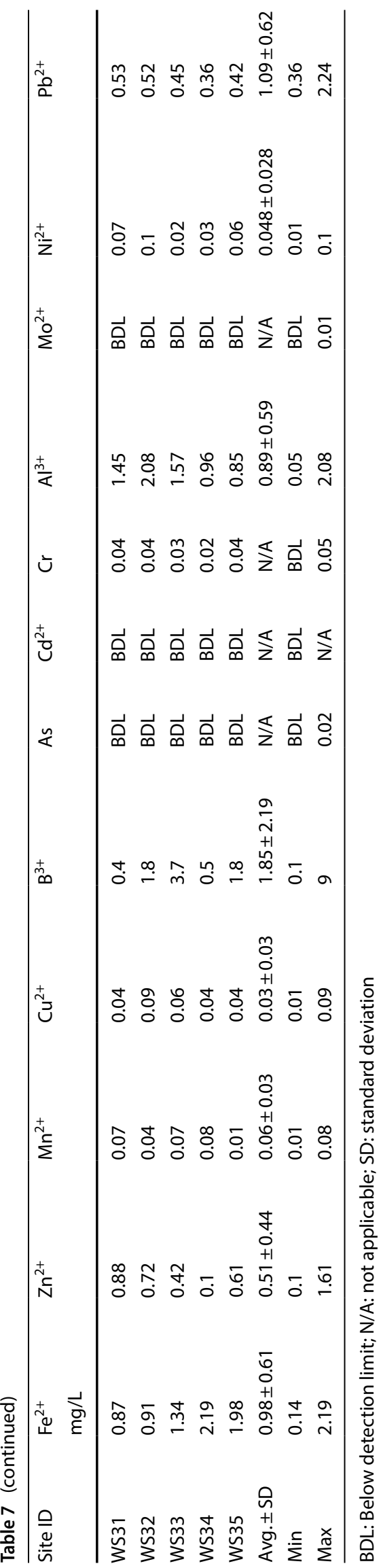




\subsection{Irrigation water anionic composition}

The Kivulini area, indicated in Table 5, had $\mathrm{NO}_{3}^{-}-\mathrm{N}$ levels ranging from 0.1 to $1.3 \mathrm{mg} \mathrm{L}^{-1}$ with a mean value of $0.83 \pm 0.41 \mathrm{mg}$ $\mathrm{L}^{-1}$ while the Nanyori area's $\mathrm{NO}_{3}^{-}-\mathrm{N}$ ranged from zero to $0.6 \mathrm{mg} \mathrm{L}^{-1}$ with an average value of $0.29 \pm 0.23 \mathrm{mg} \mathrm{L}^{-1}$ (Table 6). The $\mathrm{NO}_{3}^{-}-\mathrm{N}$ levels for the Bogoyo area ranged from zero to $1.9 \mathrm{mg} \mathrm{L}^{-1}$ with a mean value of $0.46 \pm 0.5 \mathrm{mg} \mathrm{L}^{-1}$ (Table 7). The ANOVA output values showed that the Kivulini area differed significantly in $\mathrm{NO}_{3}^{-}-\mathrm{N}$ levels with the areas of Nanyori and Bogoyo $(F=3.44, P=0.04)$ (Table S1). The $\mathrm{SO}_{4}^{2-}$ levels in the Kivulini area ranged from zero to $8 \mathrm{mg} \mathrm{L}^{-1}$ and averaged $4.7 \pm 3.3 \mathrm{mg} \mathrm{SO}_{4}^{2-} \mathrm{L}^{-1}$ (Table 5) while that of the Nanyori area ranged from zero to $2 \mathrm{mg} \mathrm{L}^{-1}$ with a mean value of $0.86 \pm 0.69 \mathrm{mg} \mathrm{L}^{-1}$ (Table 6). The Bogoyo area had its $\mathrm{SO}_{4}^{2-}$ levels ranging from zero to $7 \mathrm{mg} \mathrm{L}^{-1}$ with mean value of $1.9 \pm 2.3 \mathrm{mg} \mathrm{L}^{-1}$ (Table 7). On the other hand, the ANOVA values indicated that there were statistically significant differences in $\mathrm{SO}_{4}^{2-}$ levels among the area surveyed. The Kivulini area differed from the rest $(F=0.88, P=0.01)$ (Table $\mathrm{S} 1$ ).

The $\mathrm{Cl}^{-}$levels in the Kivulini area ranged from 0.1 to $0.4 \mathrm{mg} \mathrm{L}^{-1}$ with a mean value of $0.18 \pm 0.09 \mathrm{mg} \mathrm{L}^{-1}$ while in Nanyori area, it ranged from 0.1 to $0.5 \mathrm{mg} \mathrm{L}^{-1}$ with an average value of $0.17 \pm 0.15 \mathrm{mg} \mathrm{L}^{-1}$. For the Bogoyo area, the $\mathrm{Cl}^{-}$levels ranged from 0.1 to $0.4 \mathrm{mg} \mathrm{L}^{-1}$ with a mean value of $0.16 \pm 0.11 \mathrm{mg} \mathrm{L}^{-1}$ (Tables 5,6 and 7). The ANOVA values indicated no statistically significant differences in $\mathrm{Cl}^{-}$levels among the surveyed areas $(F=0.88, P=0.42)$ (Table S1). The Kivulini area had $\mathrm{HCO}_{3}^{-}$levels ranging from 210 to $650 \mathrm{mg} \mathrm{L}^{-1}$ and averaged $379.23 \pm 140.78 \mathrm{mg} \mathrm{L}^{-1}$ while that of the Nanyori area ranged from 300 to $460 \mathrm{mg} \mathrm{L}^{-1}$ with a mean value of $361.43 \pm 65.94 \mathrm{mg} \mathrm{L}^{-1}$. The Bogoyo area had $\mathrm{HCO}_{3}^{-}$levels ranging from 230 to $620 \mathrm{mg} \mathrm{L}^{-1}$ with a mean value of $367.65 \pm 112.67 \mathrm{mg} \mathrm{L}^{-1}$ (Tables 5, 6 and 7). Furthermore, The ANOVA values indicated that there were no statistically significant differences in the $\mathrm{HCO}_{3}^{-}$levels among the surveyed areas $(F=1.10$, $P=0.34$ ) (Table S1).

\subsection{Trace elements in irrigation water}

In this study, the $\mathrm{Fe}^{2+}$ levels in the Kivulini area ranged from 0.13 to $2.01 \mathrm{mg} \mathrm{L}^{-1}$ with an average value of $0.84 \pm 0.49 \mathrm{mg}$ $\mathrm{L}^{-1}$ while for the Nanyori area, it ranged from 0.23 to $1.63 \mathrm{mg} \mathrm{L}^{-1}$ with a mean value of $0.79 \pm 0.64 \mathrm{mg} \mathrm{L}^{-1}$. The Bogoyo area had Fe ${ }^{2+}$ levels ranging from 0.14 to $2.19 \mathrm{mg} \mathrm{L}^{-1}$ with an average value of $0.98 \pm 0.61 \mathrm{mg} \mathrm{L}^{-1}$ (Tables $5,6,7$ ). The ANOVA indicated that there were no statistically significant differences in the $\mathrm{Fe}^{2+}$ levels among the three areas surveyed $\left(F=0.39, P=0.68\right.$ ) (Table S1). The $\mathrm{Zn}^{2+}$ levels for the Kivulini area ranged from 0.12 to $1.18 \mathrm{mg} \mathrm{L}^{-1}$ with an average value of $0.39 \pm 0.34 \mathrm{mg} \mathrm{L}^{-1}$ while that of the Nanyori area ranged from 0.02 to $1.19 \mathrm{mg} \mathrm{L}^{-1}$ with an average value of $0.73 \pm 0.42 \mathrm{mg} \mathrm{L}^{-1}$ (Tables 5, 6). The Bogoyo area had $\mathrm{Zn}^{2+}$ levels ranging from 0.1 to $1.61 \mathrm{mg} \mathrm{L}^{-1}$ (Table 7). The ANOVA values indicated that there were no statistically significant differences in $\mathrm{Zn}^{2+}$ levels among three areas surveyed $(F=1.66$, $P=0.21$ ) (Table S1).

The $\mathrm{Mn}^{2+}$ levels in the Kivulini region ranged from 0.04 to $0.11 \mathrm{mg} \mathrm{L}^{-1}$ with a mean value of $0.07 \pm 0.02 \mathrm{mg} \mathrm{L}^{-1}$ (Table 5) while the Nanyori area had the $\mathrm{Mn}^{2+}$ levels ranging from 0.02 to $0.11 \mathrm{mg} \mathrm{L}^{-1}$ with an average value of $0.06 \pm 0.03 \mathrm{mg}$ $\mathrm{L}^{-1}$ (Table 6). Likewise, the Bogoyo area had the $\mathrm{Mn}^{2+}$ levels that ranged from 0.01 to $0.08 \mathrm{mg} \mathrm{L}^{-1}$ with a mean value of $0.06 \pm 0.03 \mathrm{mg} \mathrm{L}^{-1}$ (Table 7). The ANOVA output indicated that there were no statistically significant differences in $\mathrm{Mn}^{2+}$ levels among three areas surveyed $\left(F=0.87, P=0.43\right.$ ) (Table S1). Moreover, the $\mathrm{Cu}^{2+}$ levels in Kivulini area ranged from 0.01 to $0.14 \mathrm{mg} \mathrm{L}^{-1}$ with a mean value of $0.03 \pm 0.04 \mathrm{mg} \mathrm{L}^{-1}$ while for the Nanyori area $\mathrm{Cu}^{2+}$ ranged from 0.01 to $0.14 \mathrm{mg}$ $\mathrm{L}^{-1}$ and averaged $0.04 \pm 0.05 \mathrm{mg} \mathrm{L}^{-1}$ (Tables 5, 6). The Bogoyo area had $\mathrm{Cu}^{2+}$ levels ranging from 0.01 to $0.09 \mathrm{mg} \mathrm{L}^{-1}$ with a mean value of $0.03 \pm 0.03 \mathrm{mg} \mathrm{L}^{-1}$ (Table 7). The ANOVA further indicated that there were no statistically significant differences in $\mathrm{Cu}^{2+}$ levels among three areas surveyed $(F=0.64, P=0.53$ ) (Table $\mathrm{S} 1$ ). The $\mathrm{B}$ levels for the Kivulini sites ranged from 0.2 to $3.7 \mathrm{mg} \mathrm{L}^{-1}$ with a mean value of $1.45 \pm 1.06 \mathrm{mg} \mathrm{L}^{-1}$ while the Nanyori area had $B$ levels ranging from 0.3 to $2.40 \mathrm{mg} \mathrm{L}^{-1}$ with a mean value of $1 \pm 0.71 \mathrm{mg} \mathrm{L}^{-1}$ (Tables 5, 6). The Bogoyo area had B levels ranging from 0.1 to $9 \mathrm{mg} \mathrm{L}^{-1}$ with a mean value of $1.85 \pm 2.19 \mathrm{mg} \mathrm{L}^{-1}$ (Table 7). Furthermore, for $B, 32.4,54.1$, and $13.5 \%$ of the irrigation water samples indicated no toxicity, moderate toxicity, and severe toxicity, respectively $[9,10]$. Likewise, the ANOVA values indicated that there were no statistically significant differences in B levels among three areas surveyed $(F=1.07, P=0.35)$ (Table S1).

\subsection{Heavy metals in irrigation water}

The $\mathrm{Al}^{3+}$ levels in Kivulini area ranged from 0.04 to $1.2 \mathrm{mg} \mathrm{L}^{-1}$ and averaged $0.7 \pm 0.4 \mathrm{mg} \mathrm{L}^{-1}$ while the Nanyori area had $\mathrm{Al}^{3+}$ levels ranging from 0.52 to $1.59 \mathrm{mg} \mathrm{L}^{-1}$ with an average value of $1.01 \pm 0.41 \mathrm{mg} \mathrm{L}^{-1}$ (Tables 5,6$)$. Likewise, the Bogoyo area had $\mathrm{Al}^{3+}$ levels ranging from 0.05 to $2.08 \mathrm{mg} \mathrm{L}^{-1}$ with a mean value of $0.89 \pm 0.59 \mathrm{mg} \mathrm{L}^{-1}$ (Table 7). The ANOVA values 
indicated that there were no statistically significant differences in $\mathrm{Al}^{3+}$ levels among three areas surveyed $(F=1.12$, $P=0.34$ ) (Table S1). $89 \%$ of $\mathrm{Mo}^{2+}$ levels in the three areas were below the detection limit (BDL) of $0.01 \mathrm{mg} \mathrm{L}^{-1}$ (Table 5). The rest of the $\mathrm{Mo}^{2+}$ levels ranged from 0.0 to $0.01 \mathrm{mg} \mathrm{L}^{-1}$. The ANOVA values indicated that there were no statistically significant differences in $\mathrm{Mo}^{2+}$ levels among three areas surveyed $(F=0.04, P=0.96)$ (Table $\left.\mathrm{S} 1\right)$. For $\mathrm{Ni}^{2+}$, the levels in the Kivulini area ranged from 0.02 to $0.11 \mathrm{mg} \mathrm{L}^{-1}$ with a mean value of $0.06 \pm 0.02 \mathrm{mg} \mathrm{L}^{-1}$ while for the Nanyori area the $\mathrm{Ni}^{2+}$ levels ranged from 0.01 to $0.14 \mathrm{mg} \mathrm{L}^{-1}$ with a mean value of $0.06 \pm 0.05 \mathrm{mg} \mathrm{L}^{-1}$ (Tables 5, 6). The Bogoyo area had Ni ${ }^{2+}$ levels ranging from 0.01 to $0.1 \mathrm{mg} \mathrm{L}^{-1}$ with mean value of $0.05 \pm 0.03 \mathrm{mg} \mathrm{L}^{-1}$ (Table 7). The ANOVA values indicated that there were no statistically significant differences in the $\mathrm{Ni}^{2+}$ levels among the three areas surveyed $(F=1.42, P=0.26)$ (Table S1).

The $\mathrm{Pb}^{2+}$ levels in the Kivulini area ranged from 0.12 to $1.87 \mathrm{mg} \mathrm{L}^{-1}$ with a mean value of $1.02 \pm 0.61 \mathrm{mg} \mathrm{L}^{-1}$ while the Nanyori area had $\mathrm{Pb}^{2+}$ levels ranging from 0.36 to $1.84 \mathrm{mg} \mathrm{L}^{-1}$ with average value of $1.2 \pm 0.5 \mathrm{mg} \mathrm{L}^{-1}($ Tables 6,7$)$. The Bogoyo area had $\mathrm{Pb}^{2+}$ levels ranging from 0.36 to $2.24 \mathrm{mg} \mathrm{L}^{-1}$ with a mean value of $1.09 \pm 0.62 \mathrm{mg} \mathrm{L}^{-1}$ (Table 7). The ANOVA values indicated that there were no statistically significant differences in $\mathrm{Pb}^{2+}$ levels among the three areas $\left(F=1.38, P=0.87\right.$ ) (Table S1). For As and $C d$, their levels in all three areas were below the detection limit of $0.01 \mathrm{mg} \mathrm{L}^{-1}$ (Table 5). In contrast, for $\mathrm{Cr}$, the minimum value was below the method detection and the maximum value was $0.08 \mathrm{mg} \mathrm{L}^{-1}$ in the Kivulini samples; values for the Nanyori area indicated a'no detection' minimum and a maximum value of $0.04 \mathrm{mg}$ $\mathrm{L}^{-1}$ (Tables 5, 6). Likewise, for the Bogoyo sites, there was a'no detection' value for one sampling site and a maximum of $0.05 \mathrm{mg} \mathrm{Cr} \mathrm{L}^{-1}$ (Table 7).

\subsection{Irrigation water classification using Piper diagram}

The Piper diagram was plotted segregating the water samples based on the sampling areas (Kivulini, Bogoyo, and Nanyori) (Fig. 3). $\mathrm{Ca}^{2+}$ and $\mathrm{Mg}^{2+}$ dominated the cationic composition whereas $\mathrm{Cl}^{-}, \mathrm{CO}_{3}^{2-}$, and $\mathrm{HCO}_{3}^{-}$were the dominant anionic facies.

\subsection{Soil EC and pH variations}

The soil EC levels for the Kivulini area ranged from 220 to $1925 \mu \mathrm{S} \mathrm{cm}^{-1}$ with a mean value of $468 \pm 369.31 \mu \mathrm{S} \mathrm{cm}{ }^{-1}$ while for the Nanyori area the soil EC ranged from 195 to $930 \mu \mathrm{S} \mathrm{cm}^{-1}$ with a mean value of $428.29 \pm 221.62 \mu \mathrm{Scm}^{-1}$ (Tables 8 , 9). Likewise, for the Bogoyo area, the $E C$ values ranged from 195 to $930 \mu \mathrm{S} \mathrm{cm}{ }^{-1}$ with mean value of $425.21 \pm 167.43 \mu \mathrm{S}$ $\mathrm{cm}^{-1}$ (Table 10). The ANOVA values indicated that there were no statistical significance difference in EC levels among three plots in EC values $(F=0.09, P=0.92)$ (Table $S 2)$.

For soil $\mathrm{pH}$, the Kivulini area (Table 8) had values ranging from 6.31 to 8.23 with an average value of $7.43 \pm 0.60$ while for the Nanyori area (Table 9) the pH ranged from 6.75 to 8.87 with a mean value of $7.74 \pm 0.59$. The Bogoyo area had its $\mathrm{pH}$ values ranging from 7.22 to 10.09 with a mean value of $7.92 \pm 0.60$ (Table 10). The ANOVA for the pH values indicated no statistically significant difference in the $\mathrm{pH}$ levels among the three areas surveyed $(F=1.17, P=0.32)$ (Table S2).

\subsection{Soil organic carbon (OC)}

The soil OC levels in Kivulini area ranged from 0.1 to $2.4 \%$ with a mean value of $1.48 \pm 0.78 \%$; in the Nanyori area the OC ranged from 0.5 to $1.7 \%$ with a mean value of $1.29 \pm 0.37 \%$ (Tables 8,9 ). The Bogoyo area had its OC levels ranging from 0.6 to $2.4 \%$ with a mean value of $1.40 \pm 0.47 \%$ (Table 10 ). The ANOVA values for the OC indicated that there were no statistically significant differences in the OC levels among three sites surveyed $(F=0.47, P=0.63)$ (Table S2).

\subsection{Soil nutrient levels}

The Kivulini area had total $\mathrm{N}$ levels ranging from 86 to $2069 \mathrm{mg} \mathrm{kg}^{-1}$ with a mean value of $1388.95 \pm 648.26 \mathrm{mg} \mathrm{kg}^{-1}$ and that for the Nanyori sites total $\mathrm{N}$ ranged from 132 to $1896 \mathrm{mg} \mathrm{kg}^{-1}$ with a mean value of $979.5 \pm 515.26 \mathrm{mg} \mathrm{kg}^{-1}$ (Tables 8, 9). The Bogoyo sites had N levels ranging from 572 to $2155 \mathrm{mg} \mathrm{kg}^{-1}$ with an average value of $1251.46 \pm 432.78 \mathrm{mg} \mathrm{kg}^{-1}$ (Table 10). The ANOVA values indicated that there were no statistically significant differences among the three areas $(F=2.37, P=0.10$ ) (Table S2). The Kivulini sites had $P$ levels ranging from 116.12 to 
Fig. 3 Piper diagram showof irrigation water in three areas (Kivulini, Bogoyo, and Nanyori). The bottom left ternary shows the cations while bottom right ternary shows the anions. The top diamond-shaped chart represents both anions and cations distribution in the three areas surveyed

\section{EXPLANATION}

- Kivulini water

- Bogoyo water

- Nanyori water ing chemical composition

100
CATIONS

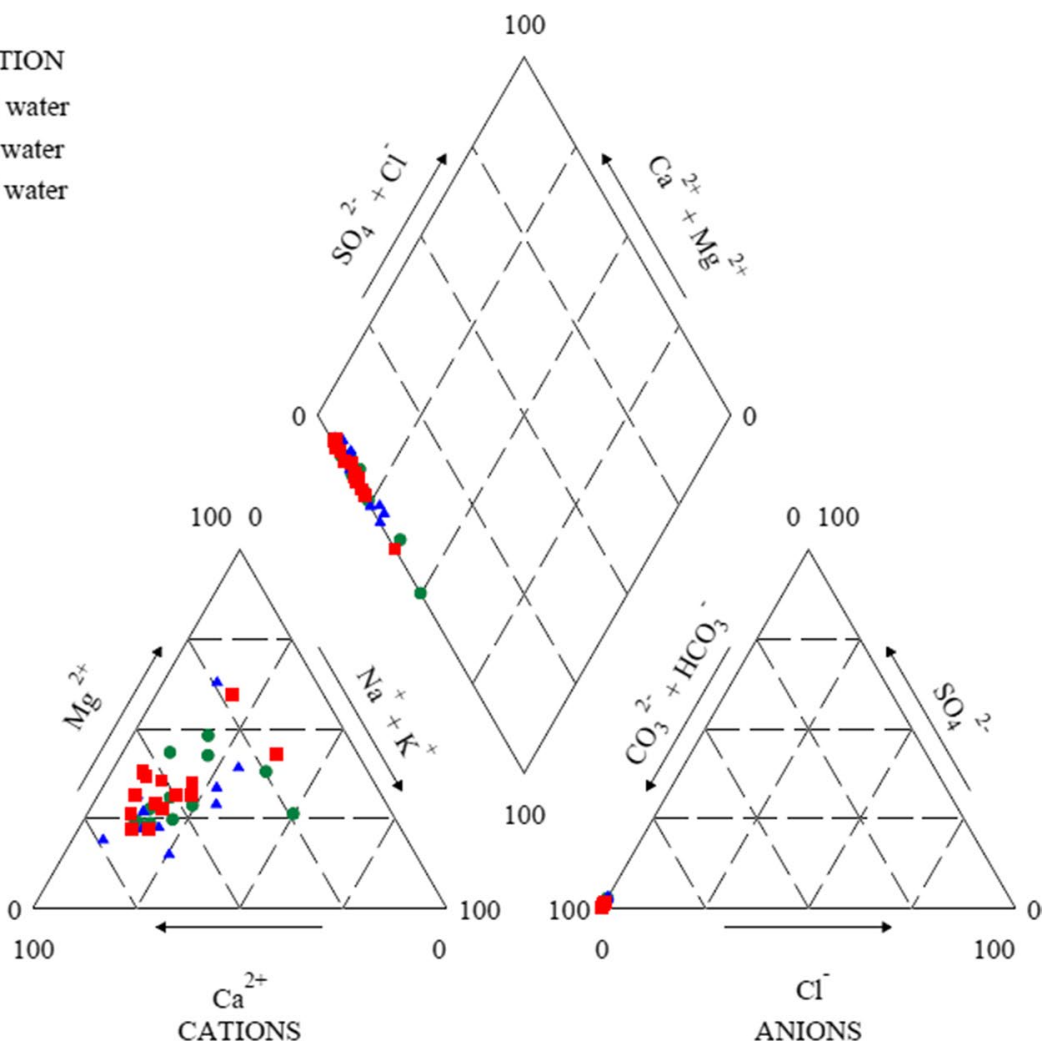

ANIONS

Table 8 Physico-chemical properties of the soils collected from the Kivulini area

\begin{tabular}{|c|c|c|c|c|c|c|c|c|}
\hline Site ID & $\mathrm{pH}$ & $\mathrm{EC}(\mathrm{mS} / \mathrm{cm})$ & OC (\%) & $\begin{array}{l}\mathrm{K} \\
\mathrm{mg} / \mathrm{kg}\end{array}$ & $\mathrm{Fe}$ & $\mathrm{Zn}$ & $P$ & TN \\
\hline SS7 & 7.58 & 404 & 2.2 & 20.12 & 5.51 & 90.17 & 142.446 & 1465 \\
\hline SS8 & 7.59 & 236 & 2.3 & 11.7 & 13.19 & 128.2 & 178.201 & 1983 \\
\hline SS9 & 7.65 & 323 & 2.4 & 13.48 & 3.28 & 72.42 & 159.341 & 2069 \\
\hline SS10 & 7.71 & 338 & 2.3 & 11.37 & 15.92 & 35.41 & 355.014 & 2069 \\
\hline SS11 & 8.23 & 320 & 2.3 & 11.34 & 5.01 & 83.36 & 227.709 & 1983 \\
\hline SS12 & 7.94 & 380 & 2.1 & 13.14 & 3.86 & 70.91 & 234.781 & 1810 \\
\hline SS13 & 7.77 & 346 & 1.2 & 14.26 & 4.13 & 68.37 & 198.371 & 1780 \\
\hline SS14 & 6.49 & 546 & 0.9 & 11.54 & 7.01 & 15.97 & 116.12 & 776 \\
\hline SS15 & 7.27 & 498 & 1.2 & 10.73 & 17.18 & 43.84 & 182.523 & 172 \\
\hline SS16 & 6.89 & 390 & 1.6 & 13.48 & 14.97 & 21.57 & 199.026 & 1379 \\
\hline SS19 & 7.33 & 303 & 2.3 & 13.9 & 3.64 & 35.54 & 129.479 & 1896 \\
\hline SS20 & 7.69 & 220 & 2.1 & 12.028 & 10.81 & 48.72 & 170.736 & 1810 \\
\hline SS21 & 6.81 & 322 & 0.3 & 11.604 & 169.49 & 49.52 & 133.016 & 1983 \\
\hline SS22 & 7.41 & 480 & 0.2 & 11.543 & 4.84 & 67.9 & 678.952 & 1509 \\
\hline SS23 & 6.31 & 296 & 0.1 & 13.812 & 9.48 & 12.78 & 136.159 & 86 \\
\hline SS24 & 8.14 & 395 & 1.3 & 16.182 & 4.43 & 17.97 & 166.807 & 690 \\
\hline SS26 & 6.31 & 636 & 1.2 & 11.694 & 22.88 & 169.74 & 481.533 & 1034 \\
\hline SS27 & 8.14 & 542 & 1.5 & 12.24 & 3.76 & 44.33 & 234.781 & 1293 \\
\hline SS28 & 7.85 & 1925 & 0.7 & 16.433 & 169.49 & 94.65 & 946.547 & 603 \\
\hline Avg. $\pm S D$ & $7.43 \pm 0.6$ & $468.42 \pm 369.32$ & $1.48 \pm 0.78$ & $13.19 \pm 2.32$ & $25.73 \pm 50.97$ & $61.65 \pm 40.18$ & $266.92 \pm 215.56$ & $1388.95 \pm 648.26$ \\
\hline Min & 6.31 & 220 & 0.1 & 10.73 & 3.28 & 12.78 & 116.12 & 86 \\
\hline Max & 8.23 & 1925 & 2.4 & 20.12 & 169.49 & 169.74 & 946.547 & 2069 \\
\hline
\end{tabular}


Table 9 Physico-chemical properties of the soils collected from the Nanyori area

\begin{tabular}{lllllllll}
\hline Site ID & $\mathrm{pH}$ & $\mathrm{EC}(\mathrm{mS} / \mathrm{cm})$ & $\mathrm{OC}(\%)$ & $\mathrm{K}$ & $\mathrm{Fe}$ & $\mathrm{Zn}$ & $\mathrm{P}$ & $\mathrm{TN}$ \\
& & & \multicolumn{2}{l}{$\mathrm{mg} / \mathrm{kg}$} & & & \\
\hline NS1 & 8.23 & 285 & 1.4 & 22.75 & 11.26 & 8.78 & 168.771 & 578 \\
NS2 & 8.10 & 488 & 0.5 & 14.538 & 58.83 & 37.14 & 173.486 & 431 \\
NS3 & 7.95 & 320 & 0.5 & 13.863 & 42.47 & 35.39 & 171.027 & 376 \\
NS4 & 8.03 & 582 & 1.2 & 13.772 & 4.26 & 13.98 & 166.807 & 517 \\
NS5 & 8.10 & 600 & 1.6 & 49.855 & 35.82 & 26.36 & 156.591 & 1379 \\
NS6 & 7.48 & 306 & 1.6 & 9.97 & 7.4 & 20.77 & 117.692 & 1552 \\
NS7 & 8.03 & 930 & 1.7 & 15.408 & 6.85 & 28.75 & 136.945 & 1896 \\
NS8 & 7.14 & 195 & 1.4 & 12.773 & 8.12 & 25.56 & 109.048 & 1034 \\
NS9 & 8.05 & 776 & 1.2 & 13.372 & 9.13 & 27.37 & 113.352 & 132 \\
NS10 & 7.44 & 247 & 1.2 & 17.627 & 24.45 & 63.5 & 136.945 & 1034 \\
NS11 & 8.87 & 387 & 1.5 & 8.899 & 154.85 & 146.18 & 144.41 & 1293 \\
NS12 & 7.01 & 240 & 1.4 & 15.373 & 7.89 & 5.48 & 386.447 & 862 \\
NS13 & 7.14 & 404 & 1.4 & 12.438 & 16.64 & 18.37 & 151.09 & 1207 \\
NS14 & 6.75 & 236 & 1.4 & 9.181 & 21.19 & 8.39 & 108.262 & 1422 \\
Avg. \pm SD & $7.74 \pm 0.59$ & $428.29 \pm 221.62$ & $1.29 \pm 0.37$ & $16.42 \pm 10.26$ & $29.23 \pm 39.57$ & $33.29 \pm 35.72$ & $160.06 \pm 69.25$ & $979.5 \pm 515.26$ \\
Min & 6.75 & 195 & 0.5 & 8.89 & 4.26 & 5.48 & 108.26 & 132 \\
Max & 8.87 & 930 & 1.7 & 49.86 & 154.85 & 146.18 & 386.45 & 1896 \\
\hline
\end{tabular}

$946.55 \mathrm{mg} \mathrm{kg}^{-}$with a mean value of $266.92 \pm 215.56 \mathrm{mg} \mathrm{kg}^{-1}$ whereas for the Nanyori area, the P levels ranged from 108.26 to $386.44 \mathrm{mg} \mathrm{kg}^{-}$with a mean value of $160.06 \pm 69.25 \mathrm{mg} \mathrm{kg}^{-1}$ (Tables 8, 9). The Bogoyo area had P levels ranging from 54.79 to $433.99 \mathrm{mg} \mathrm{kg}^{-1}$ with an average value of $227.21 \pm 113.58 \mathrm{mg} \mathrm{kg}^{-1}$ (Table 10). The ANOVA values indicated no statistically significant differences in $\mathrm{P}$ levels among the three areas surveyed $(F=2.84, P=0.07$ ) (Table S2).

The K levels for the Kivulini sites ranged from 10.73 to $20.12 \mathrm{mg} \mathrm{kg}^{-1}$ with a mean value of $13.19 \pm 2.32 \mathrm{mg} \mathrm{kg}^{-1}$ while for the Nanyori sites the $\mathrm{K}^{+}$levels ranged from 8.90 to $49.86 \mathrm{mg} \mathrm{kg}^{-1}$ with a mean value of $16.42 \pm 10.26 \mathrm{mg} \mathrm{kg}^{-1}$ (Tables 8 , 9). The Bogoyo sites had $\mathrm{K}^{+}$levels ranging from 8.83 to $24.07 \mathrm{mg} \mathrm{kg}^{-1}$ with an average value of $13.15 \pm 3.52 \mathrm{mg} \mathrm{kg}^{-1}$ (Table 10). The ANOVA values indicated no statistically significant differences in $\mathrm{K}^{+}$levels among the three areas surveyed $(F=1.84, P=0.17)$ (Table $\mathrm{S} 2)$.

\subsection{Soil trace elements}

The $\mathrm{Fe}^{2+}$ levels for the Kivulini sites ranged from 3.28 to $169.49 \mathrm{mg} \mathrm{kg}^{-1}$ with an average value of $25.73 \pm 50.97 \mathrm{mg} \mathrm{kg}^{-1}$ whereas for the Nanyori plot the $\mathrm{Fe}^{2+}$ levels ranged from 4.26 to $154.85 \mathrm{mg} \mathrm{kg}^{-1}$ with a mean value of $29.23 \pm 39.57 \mathrm{mg} \mathrm{kg}^{-1}$ (Tables 8, 9 and 10). The Bogoyo sites had $\mathrm{Fe}^{2+}$ values ranging from 2.66 to $61.73 \mathrm{mg} \mathrm{kg}^{-1}$ with a mean value of $11.21 \pm 13.64 \mathrm{mg} \mathrm{kg}^{-1}$ (Table 10). The ANOVA values indicated that there were no statistically significant difference in $\mathrm{Fe}^{2+}$ levels among the surveyed areas $(F=1.27, P=0.29)$ (Table $\mathrm{S} 2$ ).

The Kivulini sites had $\mathrm{Zn}^{2+}$ levels ranging from 12.78 to $169.74 \mathrm{mg} \mathrm{kg}^{-1}$ with mean value of $61.65 \pm 40.18 \mathrm{mg} \mathrm{kg}^{-1}$ whereas for the Nanyori area, the $\mathrm{Zn}^{2+}$ levels ranged from 5.48 to $146.18 \mathrm{mg} \mathrm{kg}^{-1}$ with an average of $33.29 \pm 35.72 \mathrm{mg} \mathrm{kg}^{-1}$ Tables 8, 9, 10. The Bogoyo sites had $\mathrm{Zn}^{2+}$ levels ranging from 3.99 to $204.09 \mathrm{mg} \mathrm{kg}^{-1}$ with a mean value of $52.14 \pm 47.94 \mathrm{mg} \mathrm{kg}^{-1}$ Table 10 . The ANOVA statistics indicated no statistically significant difference in $\mathrm{Zn}^{2+}$ levels among three areas surveyed $(F=1.67, P=0.20)$ (Table S2). 
Table 10 Physico-chemical properties of the soils collected from the Bogoyo area

\begin{tabular}{|c|c|c|c|c|c|c|c|c|}
\hline Site ID & $\mathrm{pH}$ & $\mathrm{EC}(\mathrm{mS} / \mathrm{cm})$ & OC (\%) & $\begin{array}{l}\mathrm{K} \\
\mathrm{mg} / \mathrm{kg}\end{array}$ & $\mathrm{Fe}$ & $\mathrm{Zn}$ & $P$ & TN \\
\hline SS1 & 7.63 & 930 & 1.3 & 13.13 & 8.32 & 98.13 & 125.372 & 1340 \\
\hline SS2 & 7.51 & 195 & 1.6 & 13.67 & 6.61 & 110.23 & 127.122 & 1379 \\
\hline SS3 & 7.92 & 776 & 1.5 & 18.46 & 5.92 & 76.95 & 234.388 & 690 \\
\hline SS4 & 7.66 & 247 & 2.4 & 11.01 & 61.73 & 204.09 & 230.852 & 1552 \\
\hline SS5 & 7.61 & 387 & 2.4 & 12.13 & 3.84 & 15.18 & 172.307 & 2069 \\
\hline SS12 & 9.48 & 240 & 2.3 & 12.09 & 4.27 & 39.54 & 235.174 & 2155 \\
\hline SS17 & 7.45 & 523 & 1.5 & 15.48 & 43.55 & 23.01 & 125.943 & 1293 \\
\hline SS18 & 7.76 & 564 & 2.1 & 18.49 & 4.88 & 148.17 & 136.159 & 1810 \\
\hline SS25 & 7.41 & 511 & 1.3 & 11.543 & 4.84 & 67.9 & 122.407 & 1509 \\
\hline SS29 & 8.04 & 513 & 0.9 & 16.433 & 5 & 94.65 & 433.99 & 603 \\
\hline SS30 & 7.82 & 573 & 1.6 & 24.073 & 14.9 & 109.01 & 410.415 & 1379 \\
\hline SS31 & 10.09 & 373 & 1.3 & 15.107 & 3.42 & 39.94 & 384.875 & 1121 \\
\hline SS32 & 7.72 & 353 & 1.5 & 11.374 & 2.66 & 51.12 & 373.874 & 1293 \\
\hline SS33 & 7.91 & 265 & 1.6 & 15.11 & 5.95 & 22.36 & 397.449 & 1983 \\
\hline SS34 & 7.22 & 398 & 0.9 & 15.919 & 3.28 & 5.59 & 423.381 & 776 \\
\hline SS35 & 8.66 & 307 & 1.2 & 15.264 & 5.47 & 5.37 & 396.381 & 572 \\
\hline BG1 & 8.2 & 323 & 1.6 & 9.036 & 16.9 & 15.27 & 116.298 & 1450 \\
\hline BG2 & 7.77 & 338 & 1.8 & 9.027 & 7.8 & 42.27 & 142.522 & 1270 \\
\hline BG3 & 7.74 & 320 & 1.5 & 9.082 & 4.3 & 46.73 & 151.483 & 1164 \\
\hline BG4 & 7.79 & 380 & 1.2 & 10.724 & 7.29 & 36.27 & 165.922 & 1030 \\
\hline BG5 & 7.72 & 346 & 1 & 11.642 & 34.78 & 20.37 & 184.488 & 862 \\
\hline BG6 & 8.14 & 546 & 1.3 & 10.528 & 3.42 & 29.95 & 199.419 & 1034 \\
\hline BG7 & 8.02 & 498 & 1.1 & 10.289 & 3.98 & 41.14 & 190.382 & 948 \\
\hline BG8 & 7.89 & 390 & 1 & 8.83 & 3.49 & 12.65 & 233.209 & 1552 \\
\hline BG9 & 7.66 & 523 & 1.1 & 12.865 & 16.51 & 23.56 & 177.808 & 948 \\
\hline BG10 & 7.7 & 564 & 0.9 & 11.119 & 11.38 & 71.09 & 280.359 & 1621 \\
\hline BG11 & 7.49 & 303 & 0.6 & 10.375 & 7.93 & 3.99 & 134.98 & 776 \\
\hline BG12 & 7.84 & 220 & 0.8 & 15.373 & 11.38 & 5.48 & 54.785 & 862 \\
\hline Avg. \pm SD & $7.92 \pm 0.6$ & $425.21 \pm 167.43$ & $1.4 \pm 0.47$ & $13.15 \pm 3.52$ & $11.21 \pm 13.64$ & $52.14 \pm 47.94$ & $227.21 \pm 113.58$ & $1251.46 \pm 432.78$ \\
\hline Min & 7.22 & 195 & 0.6 & 8.83 & 2.66 & 3.99 & 54.785 & 572 \\
\hline Max & 10.09 & 930 & 2.4 & 24.073 & 61.73 & 204.09 & 433.99 & 2155 \\
\hline Median & 7.765 & 383.5 & 1.3 & 12.11 & 5.935 & 39.74 & 187.435 & 1281.5 \\
\hline
\end{tabular}

\section{Discussion}

\subsection{Irrigation water EC and TDS}

The irrigation water EC or total dissolved solids (TDS) values are indicators of salinity. Saline waters have high levels of both EC and TDS due to dissolved salt ions. Highly saline waters affect crop water availability and may lead to a condition known as physiological drought [10]. The results in Table 3 indicated that the EC concentrations in 14\% of the samples posed no salinity problems to the irrigated fields whereas the remaining water samples indicated slight to moderate restriction level compared to the world Food and Agriculture Organization (FAO) guidelines and standards of other countries such as China [11]. Although the one-way ANOVA indicated no statistically significant variations for the three areas (Table S1), the area-specific TDS analysis indicated the following trends: Bogoyo > Kivulini > Nanyori. 


\subsection{SAR levels and infiltration}

Issues related to water infiltration into soils may be interpreted by combining the values of both SAR and EC together (Table 4). A small proportion (14\%) of irrigation water samples presented a slight-to-moderate infiltration problems in the study area (Table 4). The remaining proportion of the irrigation water samples had zero FAO restriction for irrigation. Furthermore, all the irrigation water samples assessed did not have severe infiltration problems for the paddy rice fields. Although the results indicated no salinity threat, a slight-to-moderate infiltration problem is a cause for concern especially due to the presence of a hardpan in the studied area and the fact that the farmers do not conduct regular leaching. Therefore, long-term use of this irrigation water will cause serious infiltration problems. The SAR values for the three areas followed the following trend: Kivulini > Bogoyo > Nanyori.

\subsection{Chloride, boron, and sodium toxicity}

$\mathrm{Cl}^{-}$levels across all irrigation water samples were well below the FAO guideline value of $4 \mathrm{meq} / \mathrm{L}[9,10,12]$. Thus, in the studied area, the irrigation water was safe from $\mathrm{Cl}^{-}$toxicity for the paddy rice fields. In the present study, $\mathrm{B}$ levels were problematic, with $\sim 68 \%$ of the irrigation water samples indicating a moderate-to-severe toxicity level (Table 5). For longterm use of irrigation water, $B$ in the irrigation water should not exceed $0.75 \mathrm{mg} \mathrm{L}^{-}$[10]. The mean $B$ values in all three areas were above the $0.75 \mathrm{mg} \mathrm{L}^{-}$cut-off point, indicating a possible $B$ toxicity. Moderate $\mathrm{Na}^{+}$toxicity in irrigation water occurs when SAR values range between 3 and 9 and there is severe $\mathrm{Na}^{+}$toxicity when $\mathrm{SAR}>9[9,10,13]$. Values of $\mathrm{SAR}<9$ in irrigation water present no potential irrigation problems [9]. For the present study, there were no $\mathrm{Na}^{+}$toxicity issues in the study area (Table 4). For $\mathrm{Cl}^{-} ; \mathrm{B}$; and $\mathrm{Na}$ ions, the mean concentrations followed the arrangement of Kivulini $>$ Nanyori > Bogoyo; Bogoyo > Kivulini > Nanyori; and Kivulini > Bogoyo > Nanyori, respectively.

\subsection{Variations in water anionic composition}

Plants require $\mathrm{N}$ to support their growth and productivity. In areas where soils are deficient in $\mathrm{N}$ content, $\mathrm{N}$ is usually supplied through the application of $\mathrm{N}$-containing fertilizers. Although $\mathrm{N}$ is important for plant growth and crop production, its excessive availability is linked to environmental degradation especially when $\mathrm{N}$ gets washed into aquatic environment, thereby causing eutrophication in the form of algal bloom. Thus, the FAO recommends that irrigation water with $\mathrm{NO}_{3}^{-}-\mathrm{N}<5 \mathrm{mg} \mathrm{L}^{-1}$ is suitable for irrigation purposes [9]. In the present study, $\mathrm{NO}_{3}^{-}-\mathrm{N}$ was found in the following trend: Kivulini > Bogoyo $>$ Nanyori. Meaning that the Kivulini area had the highest mean $\mathrm{NO}_{3}^{-} \mathrm{N}$ and the Nanyori area had the lowest. Furthermore, the ANOVA indicated that the mean $\mathrm{NO}_{3}^{-}-\mathrm{N}$ levels in the Kivulini samples significanly differed from the $\mathrm{NO}_{3}^{-}-\mathrm{N}$ means for the Nanyori and Bogoyo areas (Table S1). High levels of $\mathrm{SO}_{4}^{2-}$ in irrigation water has been linked with intensive use of synthetic fertilizers. Excessive $\mathrm{SO}_{4}^{2-}$ levels adversely affect the uptake of Ca while increasing the adsorption of $\mathrm{Na}$ and $\mathrm{K}$ leading to cation imbalances [10]. Overall, in the present study, the maximum $\mathrm{SO}_{4}^{2-}$ levels in the irrigation water was $8 \mathrm{mg} \mathrm{L}^{-1}$ in the Kivulini area. The means of $\mathrm{SO}_{4}^{2-}$ for the three surveyed areas were in the order: Kivulini > Bogoyo > Nanyori; with the concentration in the Kivulini sites showing a significant difference with those in the other two areas (Table S1). The levels of $\mathrm{SO}_{4}^{2-}$ in the present study were lower than those that were found in India $[14,15]$ and China [11].

\subsection{Irrigation water trace elements and heavy metals}

Heavy metals present in high concentrations in the environmental media may pose a health risk especially when the heavy metals get access to the food chain. Although Fe is toxic to plants, it can contribute to soil acidity and degradation of essential $\mathrm{P}$ and Mo elements [10]. In the present study, the area-by-area mean levels of $\mathrm{Fe}^{2+}$ indicated that for all samples, Fe concentration in irrigation water did not exceed $1 \mathrm{mg} / \mathrm{L}$ (Table 5) - an indication that the studied water was acceptable for irrigation. The order of Fe concentration was as follows: Bogoyo > Kivulini > Nanyori. It is important to note that the mean Fe values in the three areas surveyed did not differ significantly (Table S1). Although the recommended Zn level in irrigation water is $2 \mathrm{mg} \mathrm{L}^{-1}$, excessive $\mathrm{Zn}$ is known to be toxic to many plants [10]. $\mathrm{Zn}$ toxicity to plants occur at widely varying concentrations, but reduces at $\mathrm{pH} 6$ and above and where organic soils dominate [10]. None of the sites in this study had Zn levels above $2 \mathrm{mg} \mathrm{L}^{-1+}$ (Tables 5, 6, 7), and the ANOVA indicated no significant difference among 
the three areas surveyed (Table S1). In acidic soils, $\mathrm{Mn}$ is highly toxic to plants-therefore a restriction of $0.2 \mathrm{mg} \mathrm{L}^{-1}$ in the irrigation water has been recommended [10]. Tables 5 and S1 indicate that the $\mathrm{Mn}$ levels in the irrigation water were within the acceptable range and without spatial significant differences, respectively. A long-term use irrigation water threshold for Cu levels is at $0.2 \mathrm{mg} \mathrm{L}^{-1}$ - because $\mathrm{Cu}$ is known to adversely affect many plants in the concentration range of 0.1 to $1 \mathrm{mg} \mathrm{L}^{-1}$ [10]. In this study, Cu levels were within the ranges acceptable by FAO and did not vary significantly (Tables 5 and $\mathrm{S} 1$ ). For $\mathrm{Al}, \mathrm{Mo}, \mathrm{Ni}, \mathrm{Pb}, \mathrm{As}, \mathrm{Cd}$, and $\mathrm{Cr}$, all the measured values in irrigation water were in their acceptable ranges (Tables 5, 6, 7).

\subsection{Bicarbonate effects on irrigation water}

Of the 37 irrigation water samples, 32 indicated levels of $\mathrm{HCO}_{3}^{-}$with slight-to-moderate detrimental effect on plant growth; 5 irrigation water samples, equaling $13.5 \%$, indicated levels of $\mathrm{HCO}_{3}^{-}$with potential severe effects on plant growth [9] (Tables 5, 6, 7). For all the irrigation water samples, none indicated levels of $\mathrm{HCO}_{3}^{-}$below $1.5 \mathrm{meq} / \mathrm{L}(\sim 90 \mathrm{mg}$ $\left.\mathrm{L}^{-}\right)$, which is a safe threshold set by FAO [9]. It is possible, thus, that the observed low paddy rice productivity and variations in yields among the farmers at the study area, were attributed to elevated $\mathrm{HCO}_{3}^{-}$levels and variations.

\subsection{Water pH and nutrient levels}

The $\mathrm{pH}$ in the irrigation samples ranged between 6.3 and 7.4 (Tables $5,6,7)$ and was in an acceptable range for irrigation water $[9,13]$. Generally, the N, S, and K levels in the sampled irrigation water were within the recommended limits for agricultural application [9]. K levels in irrigation systems are not regulated because $\mathrm{K}$ has slight or no adverse effects on soil properties [16]. For $\mathrm{Ca}, \mathrm{Mg}$, and $\mathrm{Na}$, the results from the present study indicated that their average values in the irrigation water across the study area were within the acceptable limits [13].

\subsection{Irrigation water classification}

In the present study, the Piper diagram was used to elucidate the irrigation water major anionic and cationic composition [15]. The Piper diagram's bottom left ternary showed the cations while bottom right ternary showed the anions (Fig. 3). The middle diamond shape showed the chemical composition of both cations and anions. The diagram is dominated by $\mathrm{Ca}^{2+}-\mathrm{HCO}_{3}^{-}-\mathrm{Mg}^{2+}$ indicationg the irrigation water had high levels of $\mathrm{Ca}^{2+}, \mathrm{HCO}_{3}^{-}$and $\mathrm{Mg}^{2+}$ ions. Therefore, irrespective of the area from which the samples were collected, the irrigation water had salts comprised mainly of $\mathrm{Ca}^{2+}, \mathrm{HCO}_{3}^{-}$, and $\mathrm{Mg}^{2+}$ ions.

\subsection{Soil quality}

Sustainable paddy rice productivity needs to take into consideration the paddy soil properties in the irrigated scheme. Globally, soil quality variabilities in paddy fields are well recognized [17]. Paddy rice soil quality parameters such as soil EC, $\mathrm{pH}, \mathrm{OC}$, nutrients, and trace elements are important in determining sustained paddy productivity [17]. These parameters were, therefore, examined in the present study and are discussed below.

\subsection{Soil EC and pH values}

Soil EC values are indicators of soil health-it is a measure of the concentration of salts in soils [18]. Soil EC affects many other productivity indices such as soil microorganism activity, crop yields, nutrient availability, and crop suitability. Soils containing excessive EC values are common in the arid and semiarid regions of the world [18]. Factors that may lead to elevated soil EC levels include local climate, farming practices, irrigation water quality, cropping, soil inherent minerals, and texture. High soil EC levels, although not a direct measure of the presence of certain compounds, has been correlated to the presence of $\mathrm{NH}_{3}$,

$\mathrm{SO}_{4}^{2-}, \mathrm{Cl}^{+}, \mathrm{K}$, and $\mathrm{NO}_{3}^{-}$[19]. For the present study, the $\mathrm{EC}$ values ranged between 0.2 and $1.9 \mathrm{dS} / \mathrm{m}$. The overall average $\mathrm{EC}$ value was $0.45 \mathrm{dS} / \mathrm{m}$. Because the soil $\mathrm{EC}$ in the studied area was below $4 \mathrm{dS} / \mathrm{m}$, it shows that the soil in the three areas surveyed did not have salinity problems [20].

Soil $\mathrm{pH}$ is another important characteristic in paddy rice production. Rice is known to grow and flourish in soils with $\mathrm{pH}$ levels as low as 5.5 [21, 22]. However, low soil pH values may lead to nutrient leaching [23]. Thus, a slight increase 
in soil $\mathrm{pH}$ may have positive influence on paddy rice growth by improving cationic nutrient retention. In areas such as India, where $>30 \%$ of the cultivated land has acidic soils, liming to improve $\mathrm{pH}$ has been associated with improved crop production [24]. The majority of the soil samples (93\%) in the present study indicated a pH range that is favorable for paddy rice production (Tables $8,9,10$ ).

\subsection{Soil organic carbon}

Soil organic carbon (SOC) content depends on several environmental factors such as temperature, precipitation, soil water content, texture, structure, and depth from the surface. Normally, topsoil (0 to $20 \mathrm{~cm}$ depth) in the tropics are known to have the SOC content between 1.0 to 4\% [25]. It is known that SOC is important in preserving soil stability in intensively cultivated areas. However, intensive soil cultivation practices may cause changes to the physical properties of soils, causing subsequent structural degradation. Furthermore, stable soil structure has positive influence on crop yields. In the present study, SOC ranged between 0.1 and $2.4 \%$ (Table 6). This indicated good SOC in the studied soils.

\subsection{Soil macro- and micro-nutrients}

Water-soluble nutrients are an important soil characteristic. In the present study, levels of soil macro-nutrients $(\mathrm{N}, \mathrm{P}$, and $\mathrm{K}$ ) as well as micro-nutrients ( $\mathrm{Fe}$ and $\mathrm{Zn}$ ) were examined (Table 4). These are important because either their deficiency or their excessive presence has influence on paddy productivity. Major elements, i.e., $\mathrm{K}, \mathrm{N}$, and $\mathrm{P}$ are usually required by plants in large quantities. Trace elements, e.g., Fe and $\mathrm{Zn}$ are required by plants in relatively smaller amounts. In areas such as where the present study was conducted, where plant essential elements may be naturally insufficient, these elements are usually supplied to the soil by means of fertilizers.

Synthetic fertilizers are usually the main source of essential elements in soils with insufficient supply of such elements. However, excessive application of inorganic fertilizers has negative environmental impacts. Globally, the natural reserves of sulphate and phosphate rocks are dwindling, and their supply may not be sustainable in a long term-estimated to be exhausted in the next 25-100 years [26]. Therefore, good on-site fertilizer application and management is important to avoid economic and environmental repercussions. Unchecked overuse of inorganic fertilizers is not uncommon in most developing countries, including Tanzania, because such inputs represent substantial financial outlays for smallholder farmers $[27,28]$. Furthermore, remnants of excessive fertilizers used in irrigation schemes usually end up in the receiving water bodies downstream causing eutrophication [29].

In the present study, a high SD value of Fe-content in soils was computed (Table 4). First, the overall values of Fe concentration for the three areas surveyed ranged from 2.6 to $169.5 \mathrm{mg} / \mathrm{kg}$ soil (Table 4). Second, the overall mean value of Fe was $19.8 \pm 36.6 \mathrm{mg} / \mathrm{kg}$ soil, i.e., the deviation from the mean was greater than the mean itself. Because the amount of deviation in the samples was too high, the median value is a better measure of central tendency than the mean. The median value in the present study was $7.8 \mathrm{mg} / \mathrm{kg}(\mathrm{N}=61)$. This means that the concentration Fe in most of the 61 samples was close to $7.8 \mathrm{mg} / \mathrm{kg}$ soil. This could partly explain the variabilities in paddy rice yields in the studied area owing to soil Fe deficiency. A similar study in irrigated rice-growing regions of southern Brazil, for example, reported Fe levels between 159 and $324 \mathrm{mg} / \mathrm{kg}$ [30]. Another study conducted along the Ivory Coast reported Fe-content ranging from 77 to $137 \mathrm{mg} / \mathrm{kg}$ soil [31]. In a recent study, it was reported that rice plants containing 10-30 $\mathrm{mg} / \mathrm{kg}$ of Fe may be regarded as Fe deficient [32].

Zn plays an important role as a structural component of enzymes in both the plants and animals. It is also a regulator and cofactor in many biochemical processes. Zn deficiency in soils is one of the most ubiquitous problems in world agriculture. In mild Zn deficiency, paddy rice yields may be reduced, or grain quality affected with no external signs of Zn deficiency. This is called latent (or "hidden") Zn deficiency. In cases of severe (or "acute") Zn deficiencies, the results are indicated by abnormalities in plant development. Visible symptoms of $Z n$ deficiency in plants may include chlorosis and plant stunted growth. There are many soil factors that influence $\mathrm{Zn}$ availability to plants including high $\mathrm{pH}$, high concentrations of phosphate, bicarbonate, $\mathrm{Na}, \mathrm{Ca}$, and $\mathrm{Mg}$ in the soil solution. Thus, rice is a highly susceptible crop to Zn deficiency.

In the present study, the overall soil Zn levels ranged from 3.9 to $204.1 \mathrm{mg} / \mathrm{kg}$ (Table 4). The computed overall mean Zn value was $50.8 \pm 43.6 \mathrm{mg} / \mathrm{kg}$. Similar to $\mathrm{Fe}$, high variations (indicated by the high $S D$ values) in $\mathrm{Zn}$ levels were observed. The median Zn level was $37.1 \mathrm{mg} / \mathrm{kg}$. A study by the FAO conducted in 29 countries, revealed that 10 countries out of the 29 had $10 \%$ of the soil samples with potential Zn deficiency [33]. In India, 49\% of 14,863 soil samples collected from all over the country indicated Zn deficiency [34]. Although total Zn is not a good indicator of Zn deficiency, a correlation 
between total and available $\mathrm{Zn}$ has been established. Furthermore, it has been indicated that only $1.75 \%$ occurs in bioavailable forms [35].

A study conducted in Poland, found soil $\mathrm{Zn}$ levels ranging between 8.2 and $92.3 \mathrm{mg} \mathrm{Zn}$ per $\mathrm{kg}$ soil. The mean value was $41.2 \pm 24.4 \mathrm{mg} / \mathrm{kg}$ whereas the median was $38.05 \mathrm{mg} / \mathrm{kg}$ [36]. Another study conducted in China obtained soil $\mathrm{Zn}$ concentration in the range of 19.8 to $119 \mathrm{mg} / \mathrm{kg}$ soil, with a mean value of $65.5 \pm 22.2 \mathrm{mg} / \mathrm{kg}$ soil [37]. The median $\mathrm{Zn}$ concentration in the soils was found to be $61.8 \mathrm{mg} / \mathrm{kg}$ [37]. Although the mean and, somehow, the median values in previous studies were comparable to those obtained in the present study, the deviations were not. The soils in the present study may not be $\mathrm{Zn}$-deficient, but it is probable that plot-to-plot variations in paddy yields may be attributable to the variations in soil $\mathrm{Zn}$ content.

$\mathrm{N}$ is an important macro-nutrient for plants. Soil $\mathrm{N}$ deficiencies lead to poor crop growth and productivity. Excess $\mathrm{N}$ in the environment leads to environmental degradation. Elevated $\mathrm{N}$ levels may result into paddy lodging and eutrophication of disposed drainage water [38]. The source of $\mathrm{N}$ in paddy soils is either through natural supply or by addition through synthetic NPK or organic fertilizers. The amount of N naturally available in the soils is usually insufficient to support paddy rice growth. In most cases, a supply of $\mathrm{N}$ to the soils through fertilizers is required. Soil $\mathrm{N}$ content vary from place to place due to many factors such as soil type, soil pH, type and amount of fertilizer used, OC content, and climate. For example, in a long-term study on paddy rice soils in eight different regions in China, initial soil TN ranged between 920 and $2,720 \mathrm{mg} / \mathrm{kg}$ soil [39].

In the present study, the computed overall mean soil TN value was $1232 \pm 540 \mathrm{mg} / \mathrm{kg}$ (Table 4). The mean and median $(1293 \mathrm{mg} / \mathrm{kg})$ values were similar in magnitude, although the SD value from the mean was high. The overall soil TNcontent values ranged from 86 to $2155 \mathrm{mg} / \mathrm{kg}$ (Table 4). Although the range in soil TN-content in the present study seems broad, the computed median value indicates that most soil samples had TN concentration around $1293 \mathrm{mg} / \mathrm{kg}$. These values are similar to those reported in paddy rice soils of subtropical China [40]. Some previous studies have linked such high TN levels and variations to long-term fertilizer applications [41, 42]. In 2020 a local newspaper article (printed in Swahili) pointed out that the farmers in the surveyed area mentioned to researchers that they were using high amount of fertilizers and other agricultural inputs but rice production was not improving [43]. Poor on-farm practices related to agricultural inputs such as synthetic fertilizers, organic fertilizers, and pesticides may contribute to the observed variations [27]. Furthermore, such practices are known to cause economic and environmental problem in the agricultural sector [28].

After $\mathrm{N}$, soil $\mathrm{P}$ ranks second as the most essential nutrient for plant growth. Similar to $\mathrm{N}$, excess use of $\mathrm{P}$ through fertilizer has negative effects on the natural environment. It is therefore imperative to monitor the levels of $P$ in paddy rice soils. Although paddy soil total P-content may be high, only $0.1 \%$ of total P (TP) is usually available for plant uptake [44]. Historical data for tropical Asia indicate that in the 1970s the average paddy soil TP in nine Asian countries was $837 \pm 668 \mathrm{mg} / \mathrm{kg}$; range in TP concentration was from 10 to $5530 \mathrm{mg} / \mathrm{kg}$ soil [45]. The present study used this historical Asian example to lay emphasis on the lack of similar studies in sub-Saharan Africa, and to indicate the historical values of TP in tropical paddy rice soils. Soils in the least developed countries (LDCs or "the Global South") are known to contain small amounts of available P [46]. A long-term study at Rothamsted, United Kingdom, at a site where superphosphate fertilizer was used over a long time indicated that total $P$ ranged from 780 to $1425 \mathrm{mg} / \mathrm{kg}$ in the topsoil $(1-23 \mathrm{~cm})[46]$. Levels of total $P$ in the African Sahel irrigated soils were small compared to the Asian and European values reported above-whereby in soils with long-term application of P-fertilizers, the soil TP concentration was found to range between 135 and $259 \mathrm{mg} / \mathrm{kg}$ [47].

In the present paper, the soil available $\mathrm{P}($ Olsen $\mathrm{P})$ was analyzed. The results indicate that the paddy rice soil Olsen $\mathrm{P}$ values ranged between 54.8 and $946.5 \mathrm{mg} / \mathrm{kg}$ (Table 4). The overall mean Olsen $P$ value was $224.2 \pm 149.4 \mathrm{mg} / \mathrm{kg}$. The overall median value was $171 \mathrm{mg} / \mathrm{kg}$, meaning that most soil samples had Olsen $P$ values around the reported median value. A recent study by Shi et al. [48] has indicated an average critical Olsen P value of $3.40 \mathrm{mg} / \mathrm{kg}$ for rice. When compared to the values by at Rothamsted in the UK [46], it is obvious that the overall Olsen $P$ values in the present paper were extremely high. The high Olsen $\mathrm{P}$ may have had a negative impact on paddy yields. On-farm management that targets sustainable use of P-fertilizers in the studied area is therefore highly recommended. Sustainable application of P-fertilizers is recommended because of three main reasons. First, to improve paddy soil P-content in the area, hence improve crop yields. Second, globally, phosphate-containing rocks from which P-fertilizers are manufacture are rapidly declining [49]. The economic application of P-fertilizers, therefore, is of paramount importance. Third, excessive P content is known to be harmful to the natural environment.

Another highly essential plant macronutrient is K. An appropriate supply of K to plants is known to improve plants' root growth and to improve plant vigor as it helps in preventing lodging and improving plant's resistance to diseases and pests. $\mathrm{K}$ is highly mobile in both the soil and plant body. In spite of its importance to soil and plants, studies emphasizing 
on the supply of $\mathrm{K}$ to soil and plants are sparse. Most studies aim at the supply and management of $\mathrm{N}$ and $\mathrm{P}$. A previous study on $\mathrm{K}$ in soils and crops of India has recorded $\mathrm{K}$ in soil solution ranging between 1 and $10 \mathrm{mg} / \mathrm{kg}$ [50].

Slaton et al. [51] recommended soil K level of $>130 \mathrm{mg} / \mathrm{kg}$ for improved paddy rice production. In the present paper, the values of $\mathrm{K}$ ranged between 8.8 and $49.9 \mathrm{mg} / \mathrm{kg}$ soil, with a mean value of $13.9 \pm 5.6 \mathrm{mg} / \mathrm{kg}$. It is obvious that these values are too low to support good paddy rice yields. The observed low and highly varied yields reported by smallholder farmers at the study site may be attributable to low availability of $\mathrm{K}$ in the soils (Table S3).

\section{Conclusions}

To achieve high paddy rice yields, a combination of scientific information obtain at a farm and regional level is absolutely necessary. Paddy rice yields are influenced by nutrient availability, not only in the soils but also in the irrigation water. Therefore, studies that are related to nutrient-soil-water-plant interactions are important. Such studies, like the present one, provide information to farmers, agricultural extensionists, researchers and policy makers on how the quality of soils and irrigation water may influence paddy rice productivity. Although the present study focused on only one irrigation area in the Kilimanjaro region of Tanzania, the information and findings herein may be applied elsewhere in sub-Saharan Africa where similar climatic, aquatic and soil conditions prevail. It is important to note that the Asian, European, North American, and Latin American paddy rice ecosystems have been extensively studied. The sub-Saharan Africa paddy rice ecosystems, on the other hand, have only been minimally investigated. Therefore, the present study provides useful information from one of the most inadequately studied regions of the world. Although the physical characteristics of the soils were not part of the focus of the study, the authors recommend a further study into the soil characteristics because they are important for water movement and governance in the soil. Furthermore, the present study focused on the irrigation water and associated soils; however, a further study that investigates the mineral status in plants in the study area is highly recommended.

Acknowledgements The African Development Bank (AfDB) provided assistance to the Nelson Mandela African Institution of Science and Technology (NM-AIST) to support several research items of interest to the African and global scientific community. We would also want to thank International Environmental Research Institute (IERI) at Gwangju Institute of Science and Technology (GIST), South Korea for their technical support in preparing this manuscript.

Authors' contributions Data collection, analysis, and manuscript draft preparation (FMM). Data verification and quality assurance (KMM). Manuscript revision to ensure science content, clarity, and good text quality (MJR). All authors read and approved the final manuscript.

Funding No funding information to declare. The work was conducted through the generous support of the Government of Tanzania. IERI in South Korea facilitated the writing stage of the research.

Data availability Data used in the present paper are included in the manuscript and also attached as supplementary information file(s).

Code availability Not applicable.

Declarations

Ethics approval and consent to participate The present study did not involve any human or animal testing.

Competing interests The authors declare no competing interests.

Open Access This article is licensed under a Creative Commons Attribution 4.0 International License, which permits use, sharing, adaptation, distribution and reproduction in any medium or format, as long as you give appropriate credit to the original author(s) and the source, provide a link to the Creative Commons licence, and indicate if changes were made. The images or other third party material in this article are included in the article's Creative Commons licence, unless indicated otherwise in a credit line to the material. If material is not included in the article's Creative Commons licence and your intended use is not permitted by statutory regulation or exceeds the permitted use, you will need to obtain permission directly from the copyright holder. To view a copy of this licence, visit http://creativecommons.org/licenses/by/4.0/.

\section{References}

1. Awotide BA, Awoyemi TT, Omonona B, Diagne A, 10 Impact of improved agricultural technology adoption on sustainable rice productivity and rural farmers' welfare in Nigeria. Inclusive Growth in Africa: Policies, Practice, and Lessons Learnt, 2016: p. 216-37. 
2. Nkuba J, Ndunguru A, Madulu R, Lwezaura D, Kajiru G, Babu A, Chalamila B, Ley G. Rice value chain analysis in Tanzania: identification of constraints, opportunities and upgrading strategies. Afr Crop Sci J. 2016;24(1):73-87.

3. Wilson, R.T. and I. Lewis, The rice value chain in Tanzania. A Report from the Southern Highlands Food Systems Programme, FAO, 2015: $p$. 9.

4. Sierra CA, Trumbore SE, Davidson EA, Vicca S, Janssens I. Sensitivity of decomposition rates of soil organic matter with respect to simultaneous changes in temperature and moisture. J Adv Model Earth Syst. 2015;7(1):335-56.

5. Elmoghazy AM, Elshenawy MM. Sustainable cultivation of rice in Egypt. In: Negm AM, Abu-hashim M, editors. Sustainability of agricultural environment in Egypt: Part I: soil-water-food nexus. USA: Springer; 2018. p. 119-44.

6. Counce PA, Keisling TC, Mitchell AJ. A uniform, objective, and adaptive system for expressing rice development. Crop Sci. 2000;40(2):436-43. https://doi.org/10.2135/cropsci2000.402436x.

7. Akinola MO, Maphanyane JG, Mapeo RBM, Soil sampling procedures for chemical analysis, in handbook of research on geospatial science and technologies. 2018, IGI Global. p. 162-175.

8. Sattari M, Pal M, Mirabbasi R, Abraham J. Ensemble of M5 model tree based modelling of sodium adsorption ratio. J AI Data Mining. 2018;6(1):69-78.

9. Misstear B, Banks D, Clark L, Appendix 3 FAO irrigation water quality guidelines. Water Wells and Boreholes, 2006: p. 469-470.

10. Fipps, G. Irrigation water quality standards and salinity management strategies. Texas FARMER Collection, 2003. B-1667, 1-17.

11. Zhang B, Song X, Zhang Y, Han D, Tang C, Yu Y, Ma Y. Hydrochemical characteristics and water quality assessment of surface water and groundwater in Songnen plain Northeast China. Water Res. 2012;46(8):2737-48. https://doi.org/10.1016/j.watres.2012.02.033.

12. Ayers, R.S. and D.W. Westcot, Water quality for agriculture. Vol. 29. 1985, Rome, Italy: Food and Agriculture Organization of the United Nations Rome.

13. Kahimba, F., R. Ali, and H. Mahoo, Research note: evaluation of irrigation water quality for paddy production at Bumbwisudi Rice Irrigation Scheme, Zanzibar. Tanzania Journal of Agricultural Sciences, 2016. 15(2).

14. Srinivasamoorthy K, Gopinath M, Chidambaram S, Vasanthavigar M, Sarma VS. Hydrochemical characterization and quality appraisal of groundwater from Pungar sub basin, Tamilnadu, India. Journal of King Saud University - Science. 2014;26(1):37-52. https://doi. org/10.1016/j.jksus.2013.08.001.

15. Ravikumar P, Somashekar R, Prakash K. A comparative study on usage of Durov and Piper diagrams to interpret hydrochemical processes in groundwater from SRLIS river basin, Karnataka, India. Elixir International Journal. 2015;80:31073-7.

16. Smith C, Oster J, Sposito G. Potassium and magnesium in irrigation water quality assessment. Agric Water Manag. 2015;157:59-64.

17. Bhardwaj AK, Mishra VK, Singh AK, Arora S, Srivastava S, Singh YP, Sharma DK. Soil salinity and land use-land cover interactions with soil carbon in a salt-affected irrigation canal command of Indo-Gangetic plain. CATENA. 2019;180:392-400.

18. Minhas, P., T.B. Ramos, A. Ben-Gal, and L.S. Pereira, Coping with salinity in irrigated agriculture: Crop evapotranspiration and water management issues. Agricultural Water Management, 2020. 227: p. 105832.

19. Yong SK, Jalaludin NH, Brau E, Shamsudin NN, Heo CC. Changes in soil nutrients (ammonia, phosphate and nitrate) associated with rat carcass decomposition under tropical climatic conditions. Soil Res. 2019;57(5):482-8.

20. Touch S, Pipatpongsa T, Takeda T, Takemura J. The relationships between electrical conductivity of soil and reflectance of canopy, grain, and leaf of rice in northeastern Thailand. Int J Remote Sens. 2015;36(4):1136-66. https://doi.org/10.1080/01431161.2015.10072 54.

21. Yu TR. Characteristics of soil acidity of paddy soils in relation to rice growth. In: Wright RJ, Baligar VC, Murrmann RP, editors. Plant-Soil Interactions at Low pH: Proceedings of the Second International Symposium on Plant-Soil Interactions at Low pH, 24-29 June 1990, Beckley West Virginia, USA. Dordrecht: Springer, Netherlands; 1991. p. 107-12.

22. Halim A, Sa'adah N, Abdullah R, Karsani SA, Osman N, Panhwar QA, Ishak CF. Influence of soil amendments on the growth and yield of rice in acidic soil. Agronomy. 2018;8(9):165.

23. Guo X, Li H, Yu H, Li W, Ye Y, Biswas A. Drivers of spatio-temporal changes in paddy soil pH in Jiangxi Province, China from 1980 to 2010. Sci Rep. 2018;8(1):2702. https://doi.org/10.1038/s41598-018-20873-5.

24. Kumar R, Chatterjee D, Kumawat N, Pandey A, Roy A, Kumar M. Productivity, quality and soil health as influenced by lime in ricebean cultivars in foothills of northeastern India. Crop J. 2014;2(5):338-44. https://doi.org/10.1016/j.cj.2014.06.001.

25. Ramesh, T., N.S. Bolan, M.B. Kirkham, H. Wijesekara, O.W. Freeman II, N.E. Korres, N.R. Burgos, I. Travlos, M. Vurro, and R. Salas-Perez, Soil organic carbon dynamics: Impact of land use changes and management practices: A review, in Advances in Agronomy, D.L. Sparks, Editor. 2019, Academic Press Inc.: Cambridge (MA), USA.

26. White PJ, Brown PH. Plant nutrition for sustainable development and global health. Ann Bot. 2010;105(7):1073-80. https://doi.org/10. 1093/aob/mcq085.

27. White M, Heros E, Graterol E, Chirinda N, Pittelkow CM. Balancing Economic and Environmental Performance for Small-Scale Rice Farmers in Peru. Frontiers in Sustainable Food Systems. 2020. https://doi.org/10.3389/fsufs.2020.564418.

28. Kiatpathomchai S. Assessing economic and environmental efficiency of rice production systems in Southern Thailand: An application of data envelopment analysis. Justus-Liebig University Giessen, 2008.

29. Alavaisha $E$, Lyon $S$, Lindborg R. Assessment of water quality across irrigation schemes: a case study of wetland agriculture impacts in Kilombero Valley, Tanzania. Water. 2019;11(4):671. https://doi.org/10.3390/w11040671.

30. Fageria NK, Santos AB, Barbosa Filho MP, Guimarães CM. Iron toxicity in lowland rice. J Plant Nutr. 2008;31(9):1676-97. https://doi.org/ $10.1080 / 01904160802244902$

31. Sahrawat K, Jones M, Diatta S. The role of tolerant genotypes and plant nutrients in the management of acid soil infertility in upland rice. International Nuclear Information System (INIS), Switzerland, 2000.

32. Mahender A, Swamy BPM, Anandan A, Ali J. Tolerance of iron-deficient and -toxic soil conditions in rice. Plants. 2019;8(2):31. https://doi. org/10.3390/plants8020031.

33. Alloway BJ. Soil factors associated with zinc deficiency in crops and humans. Environ Geochem Health. 2009;31(5):537-48. https://doi. org/10.1007/s10653-009-9255-4.

34. Sudha S, Stalin P. Zinc deficiency in soil and role of zinc in human and plant. International Journal of Farm Sciences. 2017;7(4):30-8. 
35. Singh MV. Micronutrient deficiencies in crops and soils in India. In: Alloway BJ, editor. Micronutrient deficiencies in global crop production. Switzerland: Springer; 2008. p. 93-125.

36. Kabala C, Singh BR. Fractionation and mobility of copper, lead, and zinc in soil profiles in the vicinity of a copper smelter. J Environ Qual. 2001;30(2):485-92. https://doi.org/10.2134/jeq2001.302485x.

37. Wang XC, Yan WD, An Z, Lu Q, Shi WM, Cao ZH, Wong MH. Status of trace elements in paddy soil and sediment in Taihu Lake region. Chemosphere. 2003;50(6):707-10. https://doi.org/10.1016/s0045-6535(02)00209-6.

38. Huang J, Xu C-C, Ridoutt BG, Wang X-C, Ren P-A. Nitrogen and phosphorus losses and eutrophication potential associated with fertilizer application to cropland in China. J Clean Prod. 2017;159:171-9. https://doi.org/10.1016/j.jclepro.2017.05.008.

39. Tong C, Xiao H, Tang G, Wang H, Huang T, Xia H, Keith SJ, Li Y, Liu S, Wu J. Long-term fertilizer effects on organic carbon and total nitrogen and coupling relationships of $C$ and $N$ in paddy soils in subtropical China. Soil Tillage Res. 2009;106(1):8-14.

40. Zhang T, Chen A, Liu J, Liu H, Lei B, Zhai L, Zhang D, Wang H. Cropping systems affect paddy soil organic carbon and total nitrogen stocks (in rice-garlic and rice-fava systems) in temperate region of southern China. Sci Total Environ. 2017;609:1640-9. https://doi.org/10.1016/j. scitotenv.2017.06.226.

41. Bi L, Xia J, Liu K, Li D, Yu X. Effects of long-term chemical fertilization on trends of rice yield and nutrient use efficiency under double rice cultivation in subtropical China. Plant Soil Environ. 2014;60(12):537-43.

42. Qaswar M, Ahmed W, Jing H, Hongzhu F, Xiaojun S, Xianjun J, Kailou L, Yongmei X, Zhongqun H, Asghar W, Shah A, Zhang H. Soil carbon $(\mathrm{C})$, nitrogen $(\mathrm{N})$ and phosphorus $(\mathrm{P})$ stoichiometry drives phosphorus lability in paddy soil under long-term fertilization: A fractionation and path analysis study. PLoS ONE. 2019;14(6): e0218195. https://doi.org/10.1371/journal.pone.0218195.

43. Mushi G. Wafanya utafiti uzalishaji mpunga (Researchers and rice production), in Nipashe. Dar Es Salaam: IPP Media Group; 2020.

44. Khan MMA, Haque E, Paul NC, Khaleque MA, Al-Garni SMS, Rahman M, Islam MT. Enhancement of growth and grain yield of rice in nutrient deficient soils by rice probiotic bacteria. Rice Sci. 2017;24(5):264-73. https://doi.org/10.1016/j.rsci.2017.02.002.

45. Kawaguchi K, Kyuma K. Paddy soils in Tropical Asia: Part 5. Soil fertility evaluation. Jpn J Southeast Asian Stud. 1975;13(3):385-401.

46. Syers, J, Johnston A, Curtin D, Efficiency of soil and fertilizer phosphorus use. FAO Fertilizer and plant nutrition bulletin, 2008. 18(108).

47. Haefele SM, Wopereis MCS, Schloebohm AM, Wiechmann H. Long-term fertility experiments for irrigated rice in the West African Sahel: effect on soil characteristics. Field Crop Res. 2004;85(1):61-77. https://doi.org/10.1016/s0378-4290(03)00153-9.

48. Shi L-L, Shen M-X, Lu C-Y, Wang H-H, Zhou X-W, Jin M-J, Wu T-D. Soil phosphorus dynamic, balance and critical P values in long-term fertilization experiment in Taihu Lake region, China. J Integr Agric. 2015;14(12):2446-55. https://doi.org/10.1016/s2095-3119(15)61183-2.

49. Cordell D, Drangert J-O, White S. The story of phosphorus: Global food security and food for thought. Glob Environ Chang. 2009;19(2):292305. https://doi.org/10.1016/j.gloenvcha.2008.10.009.

50. Sekhon G. Potassium in Indian soils and crops. Proc Indian Natl Sci Acad B. 1999;65:83-108.

51. Slaton NA, Golden BR, Norman RJ, Wilson CE, DeLong RE. Correlation and calibration of soil potassium availability with rice yield and nutritional status. Soil Sci Soc Am J. 2009;73(4):1192-201.

Publisher's Note Springer Nature remains neutral with regard to jurisdictional claims in published maps and institutional affiliations. 